\title{
Direct C-H Borylation of Arenes Catalyzed by Saturated Hydride- Boryl-Iridium-POP Complexes: Kinetic Analysis of the Elemental Steps
}

\author{
Miguel A. Esteruelas, ${ }^{*[a]}$ Antonio Martínez, ${ }^{[a]}$ Montserrat Oliván, ${ }^{[a]}$ and Enrique Oñate ${ }^{[a]}$ \\ [a] Prof. Dr. M. A. Esteruelas, A. Martínez, Dr. M. Oliván, Dr. E. Oñate \\ Departamento de Química Inorgánica, Instituto de Síntesis Química y Catálisis Homogénea (ISQCH), Centro de Innovación en Química Avanzada \\ (ORFEO-CINQA), Universidad de Zaragoza - CSIC, 50009 Zaragoza, Spain \\ E-mail: maester@unizar.es
}

Supporting information for this article is given via a link at the end of the document.

\begin{abstract}
The saturated trihydride $\operatorname{IrH}_{3}\left\{\mathrm{~K}^{3}-\mathrm{P}, \mathrm{O}, \mathrm{P}-\left[\mathrm{xant}\left(\mathrm{P}^{\mathrm{i}} \mathrm{Pr}_{2}\right)_{2}\right]\right\}$ (1; xant $\left(\mathrm{P}^{\mathrm{i}} \mathrm{Pr}_{2}\right)_{2}=$ 9,9-dimethyl-4,5-bis(diisopropylphosphino)xanthene) activates the $\mathrm{B}-\mathrm{H}$ bond of two molecules of pinacolborane (HBpin) to give $\mathrm{H}_{2}$ and the hydride-boryl derivatives $\operatorname{IrH}_{2}(\mathrm{Bpin})\left\{\mathrm{K}^{3}-\mathrm{P}, \mathrm{O}, \mathrm{P}-\right.$ [xant $\left.\left.\left(\mathrm{P}^{\mathrm{i}} \mathrm{Pr}_{2}\right)_{2}\right]\right\}$ (2) and $\operatorname{IrH}(\mathrm{Bpin})_{2}\left\{\mathrm{~K}^{3}-\mathrm{P}, \mathrm{O}, \mathrm{P}-\left[\mathrm{xant}\left(\mathrm{P}^{\mathrm{i}} \mathrm{Pr}_{2}\right)_{2}\right]\right\}$ (3) in a sequential manner. Complex 3 activates a $\mathrm{C}-\mathrm{H}$ bond of two molecules of benzene to form PhBpin and regenerates $\mathbf{2}$ and $\mathbf{1}$ also in a sequential manner. Thus, complexes $\mathbf{1}, 2$, and 3 define two cycles for the catalytic direct $\mathrm{C}-\mathrm{H}$ borylation of arenes with HBpin, which have the dihydride 2 as a common intermediate. The $\mathrm{C}-\mathrm{H}$ bond activation of the arenes is the rate determining step of both cycles, being the $\mathrm{C}-\mathrm{H}$ oxidative addition to $\mathbf{3}$ faster than to 2 . Results from the kinetic study of the reactions of $\mathbf{1}$ and $\mathbf{2}$ with HBpin support a cooperative function of the hydride ligands in the $\mathrm{B}-\mathrm{H}$ bond activation. The addition of the boron atom of the borane to a hydride facilitates the coordination of the $\mathrm{B}-\mathrm{H}$ bond through the formation of $\mathrm{K}^{1}$ - and $\mathrm{K}^{2}$-dihydrideborate intermediates.
\end{abstract}

\section{Introduction}

The direct $\mathrm{C}-\mathrm{H}$ bond functionalization is one of the most powerful, valuable, and straightforward methods for transforming low cost hydrocarbons in valuable products. ${ }^{[1]}$ Transition-metal complexes, most notably those of the platinum group, have the remarkable ability to enhance the reactivity of some $\mathrm{C}-\mathrm{H}$ bonds while inhibiting the reactions of others of the same molecule. ${ }^{[2]}$ As a consequence, the metal-mediated $\mathrm{C}-\mathrm{H}$ activation-coupling processes are efficacious tools in the current organic synthesis. ${ }^{[3]}$ In this context, the versatility of the organoboron compounds $^{[4]}$ makes the design of catalysts for selective $\mathrm{C}-\mathrm{H}$ bond borylation a particularly attractive goal, ${ }^{[5]}$ being the study of the elemental steps of the catalysis the key.

The $\mathrm{C}-\mathrm{H}$ borylation of arenes without the use of directing groups provides products with regioselectivities which are mainly governed by steric reasons. ${ }^{[5 a-c]}$ Although catalytic activity has been observed with complexes of several metals, including iron, ${ }^{[6]}$ cobalt, ${ }^{[7]}$ rhodium, ${ }^{[8]}$ nickel, ${ }^{[9]}$ and platinum, ${ }^{[10]}$ the most prominent catalysts appear to be those of iridium. ${ }^{[1]}$ It is generally accepted that the active species are 16e-iridium(III) complexes of formula $\operatorname{Ir}(\mathrm{Bpin})_{3} \mathrm{~L}_{2}$, where $\mathrm{L}_{2}$ represents two $2 \mathrm{e}$ donor ligands or is a $4 \mathrm{e}^{-}$donor $\mathrm{P}_{-}{ }^{[12]}$ or $\mathrm{N}$-bidentate ${ }^{[13]}$ Lewis base. They are generated in situ by combination of a metal precursor, usually $[\operatorname{Ir}(\mu-\mathrm{OMe})(\mathrm{COD})]_{2} \quad(\mathrm{COD}=1,5-$ cyclooctadiene), the Lewis base, and pinacolborane (HBpin).
According to the catalytic cycle proposed on the base of experimental support and DFT calculations (Scheme 1), these unsaturated compounds activate a $\mathrm{C}-\mathrm{H}$ bond of the arene to afford the borylated organic product and intermediates $\operatorname{IrH}(\text { Bpin })_{2} \mathrm{~L}_{2}$, which react with the borane to regenerate the catalyst and release molecular hydrogen via dihydrogeniridium(III) or dihydride-iridium(V) derivatives. ${ }^{[14]}$ In recent years, some significant modifications to $\operatorname{Ir}(\text { Bpin })_{3} \mathrm{~L}_{2}$ have been performed. By using $3 \mathrm{e}^{-}$donor $\mathrm{BN},{ }^{[15]} \mathrm{SiN}$, and $\mathrm{SiP}^{[16]}$ chelate ligands, 14e-iridium(III) species have been generated, which are particularly active for the $\mathrm{C}-\mathrm{H}$ borylation of sterically hindered substrates.

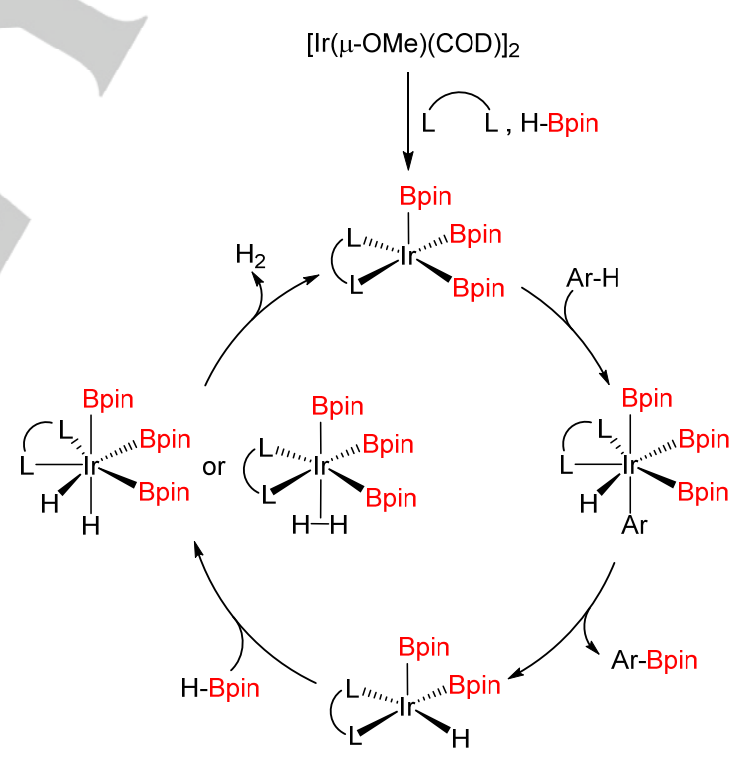

Scheme 1. Proposed catalytic cycle for the borylation of arenes catalyzed by $\operatorname{Ir}(\text { Bpin })_{3} \mathrm{~L}_{2}$

Pincer ligands have opened novel approaches in catalysis. $^{[17]}$ However, they have been scarcely used for stabilizing $\mathrm{C}-\mathrm{H}$ borylation catalysts. Three classes of pincers have received attention: neutral $6 \mathrm{e}^{-}$donors, ${ }^{[6 \mathrm{~d}, 7]}$ monoanionic $5 \mathrm{e}$ donors, ${ }^{[6 c, 8 b, 10 b, 18]}$ and dianionic $4 \mathrm{e}^{-}$donors. ${ }^{[19]}$ The first type has been employed by the groups of Chirik, Cui, and Kamitani. Chirik $^{[7 a-c, e-j]}$ has developed cobalt complexes bearing NNN, NNP, PNP, and PPP ligands, which promote reactions of heterocycles and arenes through a cycle that relies on a cobalt(I)-(III) redox couple. Cui ${ }^{[7 d]}$ has synthesized a cobalt(II) compound stabilized 
by a silylene-pyridine-silylene pincer, which enables reactions of pyridines, furans, and fluorinated arenes, whereas Kamitani ${ }^{[6 d]}$ has achieved efficient $\mathrm{C}-\mathrm{H}$ borylation of arenes and heteroarenes using an iron complex bearing a quinoline-based PNN ligand. Pincers donating $5 \mathrm{e}^{-}$and $4 \mathrm{e}^{-}$have been mainly used to stabilize iridium catalysts, ${ }^{[18,19]}$ in addition to some examples of iron, ${ }^{[6]}$ rhodium, ${ }^{[8 b]}$ and platinum. ${ }^{[10 b]}$ Chianese's group ${ }^{[18 \mathrm{a}]}$ has observed that, in combination with $\mathrm{NaO}{ }^{t} \mathrm{Bu}$, iridium(III) complexes containing CCC-pincer $\mathrm{N}$-heterocyclic carbene ligands form active species for $\mathrm{C}-\mathrm{H}$ borylation of disubstituted substrates. Nishiyama's group ${ }^{[18 c]}$ has reported that the acetate derivative $\operatorname{Ir}(\mathrm{OAc})_{2}($ phebox $)\left(\mathrm{H}_{2} \mathrm{O}\right)$ (phebox $=$ bis(oxazolinyl)phenyl) promotes the reactions with benzene and monosubstituted arenes. The Shimada's group ${ }^{[18 b]}$ has described the preparation of iridium(III) unsaturated complexes with a PSiP pincer diphosphine, which catalyze the $\mathrm{C}-\mathrm{H}$ borylation of benzene with $\mathrm{B}_{2} \mathrm{pin}_{2}$, whereas Driess, Hartwig and co-workers $^{[18 d]}$ have reported that iridium(III) precursors with bulky silylene-aryl-silylene pincers work for the reactions with HBpin. Recently, Li's group has used a NNB-boryl ligand, ${ }^{[18 f]}$ whereas Pérez-Torrente, Oro, and co-workers ${ }^{[19]}$ have isolated unsaturated catalysts supported by an ONO ligand. From a mechanistic point of view, it should be noteworthy the Ozerov's studies on (POCOP)Ir systems, which have allowed them to conclude that the $\mathrm{C}-\mathrm{H}$ bond activation of the arene occurs on an iridium(I) center devoid of boryl ligands (Scheme 2), ${ }^{[18 \mathrm{e}]}$ in contrast to the catalysts supported by neutral bidentate ligands.

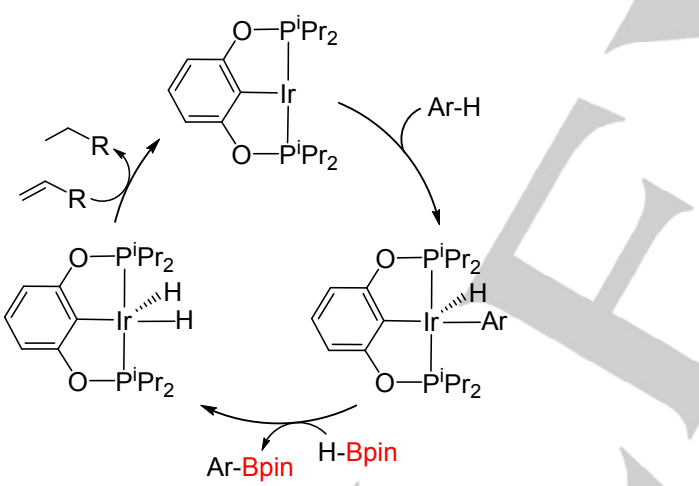

Scheme 2. Proposed mechanism for the borylation of arenes catalyzed by $\operatorname{Ir}(\mathrm{POCOP})$ systems.

Ether-diphosphines are neutral hemilabile POP pincer ligands donating $6 \mathrm{e}^{-}$. They have special interest by their flexibility, which grants the ability to change their coordination fashion between $\mathrm{k}^{3}-\mathrm{mer}, \mathrm{k}^{3}-\mathrm{fac}$, and $\mathrm{K}^{2}$. As a consequence, they can be adapted to the requirements of the catalytic intermediates, playing relevant roles in catalysis. ${ }^{[20]}$ 9,9-Dimethyl-4,5bis(diisopropylphosphino)xanthene $\left(x a n t\left(P^{i} P_{2}\right)_{2}\right)$ is a ligand of this class, ${ }^{[11]}$ which has demonstrated to have a higher capacity than other POP-diphosphines to act as pincer. ${ }^{[22]}$ It even gets to stabilize the mer-trisboryl derivative $\operatorname{Ir}(\mathrm{Bcat})_{3}\left\{\mathrm{~K}^{3}-\mathrm{P}, \mathrm{O}, \mathrm{P}\right.$ [xant $\left.\left.\left(\mathrm{P}^{\mathrm{i}} \mathrm{Pr}_{2}\right)_{2}\right]\right\}$, which challenges the concept of transinfluence ${ }^{[23]}$ In spite of it, complexes of groups 8, 9, and 10 with $\mathrm{K}^{3}$-fac-POP- and cis- and trans- $\mathrm{K}^{2}-\mathrm{POP}-$ coordination of xant $\left(\mathrm{P}^{\mathrm{i}} \mathrm{Pr}_{2}\right)_{2}$ have been also reported. ${ }^{[24]}$ Thus, compounds bearing this pincer ligand have displayed notable activity in processes related to the hydrogen economy, ${ }^{[24,25]}$ in addition to a wide range of interesting organic reactions ${ }^{[24 b, 26]}$ including borylations. ${ }^{[8 a, 27]}$ Thus, it has been demonstrated that the square-planar rhodium(I) complexes $\mathrm{Rh}(\mathrm{Bpin})\left\{\mathrm{K}^{3}-\mathrm{P}, \mathrm{O}, \mathrm{P}-\right.$ [xant $\left.\left.\left(\mathrm{P}^{\mathrm{i}} \mathrm{Pr}_{2}\right)_{2}\right]\right\}, \quad \mathrm{RhH}\left\{\mathrm{K}^{3}-\mathrm{P}, \mathrm{O}, \mathrm{P}-\left[\mathrm{xant}\left(\mathrm{P}^{\mathrm{i}} \mathrm{Pr}_{2}\right)_{2}\right]\right\}, \quad$ and $\mathrm{Rh}(\operatorname{aryl})\left\{\mathrm{K}^{3}-\right.$ $\left.\mathrm{P}, \mathrm{O}, \mathrm{P}-\left[\mathrm{xant}\left(\mathrm{P}^{\mathrm{i}} \mathrm{Pr}_{2}\right)_{2}\right]\right\}$ are involved in the direct $\mathrm{C}-\mathrm{H}$ borylation of arenes according to Scheme $3 .^{[8 a]}$

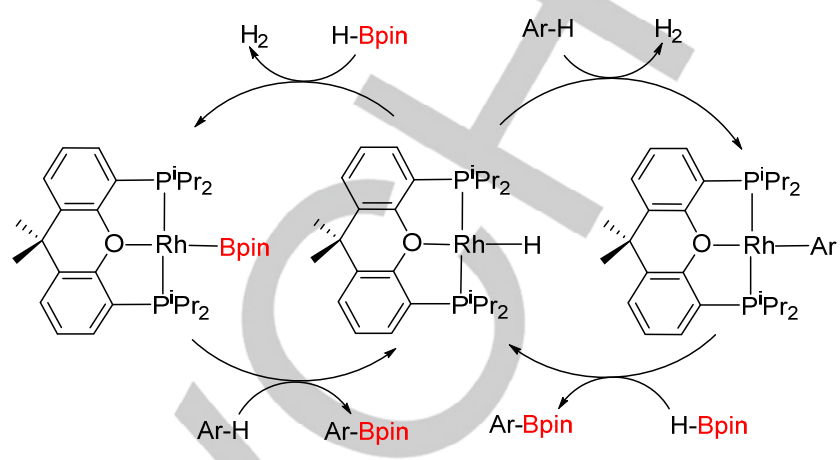

Scheme 3. Mechanism of the borylation of arenes catalyzed by $\mathrm{Rh}(\mathrm{POP})$ systems.

The behavior of the $\mathrm{Rh}^{(1)}\left\{\mathrm{K}^{3}-\mathrm{P}, \mathrm{O}, \mathrm{P}-\left[\mathrm{xant}\left(\mathrm{P}^{\mathrm{i}} \mathrm{Pr}_{2}\right)_{2}\right]\right\}$ system inspired us to developing an iridium counterpart. In the search for an Ir-POP catalyst for the direct $\mathrm{C}-\mathrm{H}$ borylation of arenes, we have studied the $\mathrm{B}-\mathrm{H}$ bond activation of $\mathrm{HBpin}$ promoted by the trihydride $\operatorname{IrH}_{3}\left\{\mathrm{~K}^{3}-\mathrm{P}, \mathrm{O}, \mathrm{P}-\left[\mathrm{xant}\left(\mathrm{P}^{\mathrm{i}} \mathrm{Pr}_{2}\right)_{2}\right]\right\}$ (1). Although the sixcoordinate $5 d^{6}$ metal center of this compound exhibits a strong octahedral $\Delta_{0}$ splitting, which is low spin and maximizes the ligand-field stabilization energy, ${ }^{[28]}$ and furthermore $x a n t\left(\mathrm{P}^{\mathrm{i}} \mathrm{Pr}_{2}\right)_{2}$ has a strong tendency to act as pincer, ${ }^{[22,23]}$ we reasoned that in view of the presence of empty orbitals at the boron atom of the borane and the basic character of the hydride ligand, ${ }^{[2]}$ the latter would be cooperating in the coordination action of HBpin. The addition of a borane to a hydride ligand of a transition metal complex is a well-known reaction ${ }^{[30]}$ and the resulting dihydrideborate can coordinate both $\mathrm{K}^{1}-\mathrm{H}$ and $\mathrm{k}^{2}-\mathrm{H}, \mathrm{H} \cdot{ }^{[31]}$

This paper shows the preparation of a saturated-iridium catalytic system for the direct borylation of arenes and studies the kinetic of the elemental stages of the catalysis, demonstrating that the hydride ligands in fact facilitate the coordination of the borane to the metal center and their presence is therefore desirable in this type of catalysts.

\section{Results and Discussion}

Reactions of the trihydride 1 with HBpin: Characterization of the reactions products. This trihydride activates the $\mathrm{B}-\mathrm{H}$ bond of two molecules of HBpin in a sequential manner. The products of the activations are shown in Scheme 4.

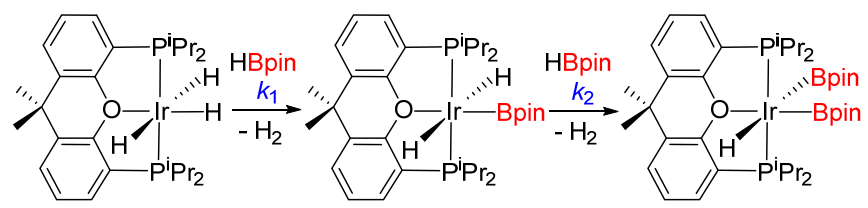
1 2 3

Scheme 4. Reactions with pinacolborane. 
Treatment of 1 with 1.0 equiv of HBpin, in octane, at room temperature, for $8 \mathrm{~h}$ leads to the dihydride-boryl derivative $\mathrm{IrH}_{2}$ (Bpin) $\left\{\mathrm{K}^{3}-\mathrm{P}, \mathrm{O}, \mathrm{P}-\left[\mathrm{xant}\left(\mathrm{P}^{\mathrm{i}} \mathrm{Pr}_{2}\right)_{2}\right]\right\}$ (2) and molecular hydrogen, as a result of the $\mathrm{B}-\mathrm{H}$ bond activation of borane. Complex 2 was isolated as a white solid in $60 \%$ yield and characterized by $\mathrm{X}$-ray diffraction analysis. The structure (Figure 1 ) reveals a disposition trans for the hydride ligands $\left(\mathrm{H}(01)-\mathrm{Ir}-\mathrm{H}(02)=176.3(12)^{\circ}\right)$. The coordination polyhedron around the iridium center can be described as a distorted octahedron with the ether-diphosphine coordinated mer $\left(\mathrm{P}(1)-\operatorname{Ir}-\mathrm{P}(2)=162.35(2)^{\circ}, \mathrm{P}(1)-\mathrm{Ir}-\mathrm{O}(3)=\right.$ $\left.81.35(5)^{\circ}, \mathrm{P}(2)-\operatorname{Ir}-\mathrm{O}(3)=81.76(5)^{\circ}\right)$ and the boryl group disposed trans to the oxygen atom of the pincer $(\mathrm{B}(1)-\mathrm{Ir}-\mathrm{O}(3)=$ $178.27(9)^{\circ}$ ) The Ir-B(1) distance of 1.994(3) $\AA$ compares well the length of the bond Ir-B disposed trans to the oxygen atom of the diphosphine in the mer-trisboryl derivative $\operatorname{Ir}(\mathrm{Bcat})_{3}\left\{\mathrm{~K}^{3}-\mathrm{P}, \mathrm{O}, \mathrm{P}\right.$ [xant $\left.\left.\left(\mathrm{P}^{\mathrm{i}} \mathrm{Pr}_{2}\right)_{2}\right]\right\}(2.012(10) \AA) .{ }^{[23]}$ According to the presence of two equivalent hydrides in the complex, the ${ }^{1} \mathrm{H}$ NMR spectrum of the colorless crystals, in $\left[D_{6}\right]$ benzene, at room temperature displays a triplet $\left({ }^{2} J_{\mathrm{H}-\mathrm{P}}=17.5 \mathrm{~Hz}\right)$ at $-6.11 \mathrm{ppm}$ whereas the ${ }^{31} \mathrm{P}\left\{{ }^{1} \mathrm{H}\right\} \mathrm{NMR}$ spectrum shows a singlet at $57.8 \mathrm{ppm}$, for the equivalent $\mathrm{P}^{\mathrm{i}} \mathrm{Pr}_{2}$ groups, which splits into a triplet under off-resonance decoupling conditions. The ${ }^{11} \mathrm{~B}\left\{{ }^{1} \mathrm{H}\right\}$ NMR spectrum contains a broad resonance centered at $34.2 \mathrm{ppm}$. decoupling conditions, whereas the ${ }^{11} \mathrm{~B}$ contains a broad signal centered at $38.4 \mathrm{ppm}$.

The reactions of 1 and $\mathbf{2}$ with DBpin were also carried out in order to know the position of the BH-hydrogen atom in the final products. The addition of 1.0 equiv of DBpin, to both $\left[D_{12}\right]$ cyclohexane and cyclohexane solutions of 1 , at room temperature led to equimolecular mixtures of $\mathbf{2}$ and $\mathbf{2}-\boldsymbol{d}_{\mathbf{1}}\left(\delta_{\mathrm{H}},-\right.$ $\left.6.08 ; \delta_{\mathrm{D}},-6.09\right)$. It is worth noting that the hydride chemical shift of $\mathbf{2}-\boldsymbol{d}_{\mathbf{1}}$ is slightly shifted towards downfield with regard to that of 2, due to the higher trans effect of deuteride. ${ }^{[32]}$ Under the same conditions, the reaction of 2 with DBpin afforded equimolecular mixtures of $\mathbf{3}$ and $\mathbf{3}-\boldsymbol{d}_{1}\left(\delta_{\mathrm{D}},-5.76\right)$. The formation of $\mathbf{2}$ and $\mathbf{3}$ according to Scheme 5 suggests that the rupture of the H-B bond occurs before the release of the hydrogen molecule. So, the reductive elimination of $\mathrm{H}_{2}$ from 1 and 2 to afford the corresponding iridium $(\mathrm{I})$ species, which add the $\mathrm{B}-\mathrm{H}$ bond of the borane to give 2 and $\mathbf{3}$, respectively, must be rejected.

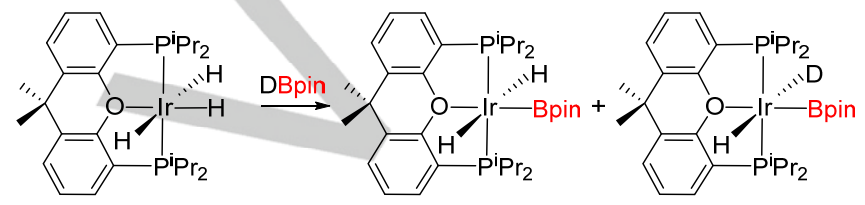

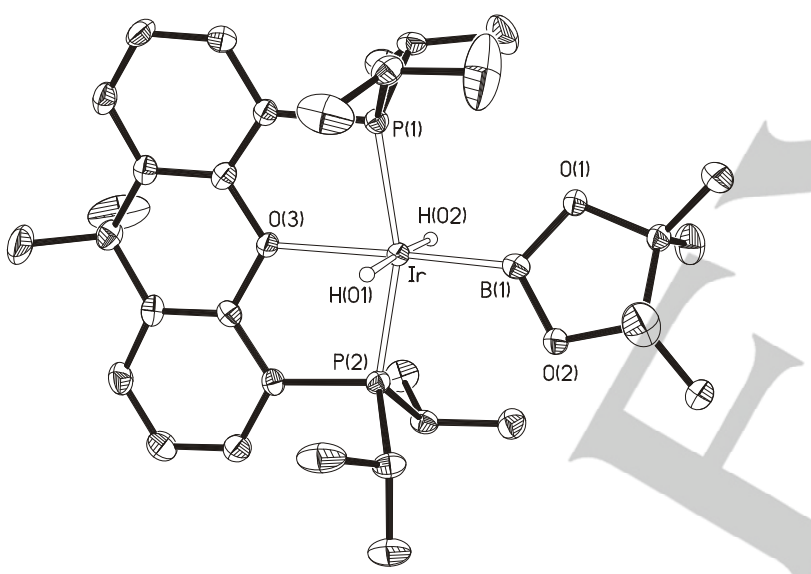

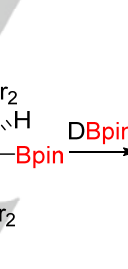

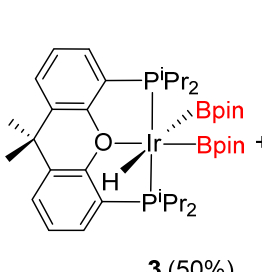

$3(50 \%)$

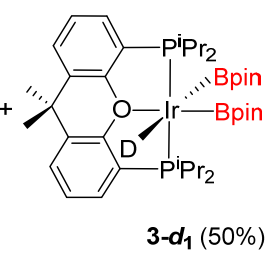

Scheme 5. Reactions with DBpin.

Kinetic and Mechanism of the B-H bond Activations. The transformations, in octane, from 1 into $2\left(k_{1}\right)$ and from 2 into 3 $\left(k_{2}\right)$ were independently followed by ${ }^{31} \mathrm{P}\left\{{ }^{1} \mathrm{H}\right\}$ NMR spectroscopy in the temperature range $323-363 \mathrm{~K}$, for concentrations of HBpin between 0.76 and $1.52 \mathrm{M}$ and initial concentrations of 1 and 2 of $3.73 \times 10^{-2} \mathrm{M}$. Under these conditions, the decreases of $\mathbf{1}$ and $\mathbf{2}$ with the respective increases of $\mathbf{2}$ and $\mathbf{3}$ are exponential functions of the time, according to pseudo-first-order processes. The rate constants $k_{1}{ }^{\text {obs }}$ and $k_{2}{ }^{\text {obs }}$ for each concentration of HBpin used are given in Table 1 . They were calculated by means of the graphical representations (Figures 2 and 3 ) of the expressions:

$$
\begin{aligned}
& \ln \frac{[\mathbf{1}]}{[\mathbf{1}]_{0}}=-k_{1}^{o b s} t \\
& \ln \frac{[\mathbf{2}]}{[\mathbf{2}]_{0}}=-k_{2}^{o b s} t
\end{aligned}
$$


Table 1. Rate constants for the transformations of $\mathbf{1}$ into $\mathbf{2}\left(k_{1}{ }^{\text {obs }}\right.$ and $k_{1}$, calculated according to eqs 1 and 4 , respectively) and of 2 into 3 ( $k_{2}{ }^{\text {obs }}$ and $k_{2}$, calculated according to eqs 2 and 6 , respectively)

\begin{tabular}{|c|c|c|c|c|c|c|c|c|}
\hline $\begin{array}{c}\mathrm{T} \\
(\mathrm{K})\end{array}$ & $\begin{array}{l}{[1]_{0}} \\
(\mathrm{M})\end{array}$ & $\begin{array}{l}{[2] \text { 。 }} \\
(\mathrm{M})\end{array}$ & $\begin{array}{c}\text { [HBpin] } \\
\text { (M) }\end{array}$ & $\begin{array}{c}\text { [DBpin] } \\
\text { (M) }\end{array}$ & $\begin{array}{c}k_{1}{ }^{\text {obs }} \times 10^{-3} \\
\left(\mathrm{~s}^{-1}\right)\end{array}$ & $\begin{array}{l}k_{1} \times 10^{-3} \\
\left(\mathrm{M}^{-1} \mathrm{~s}^{-1}\right)\end{array}$ & $\begin{array}{c}k_{2}{ }^{\text {obs }} \times 10^{-3} \\
\left(\mathrm{~s}^{-1}\right)\end{array}$ & $\begin{array}{l}k_{2} \times 10^{-3} \\
\left(\mathrm{M}^{-1} \mathrm{~s}^{-1}\right)\end{array}$ \\
\hline 323 & 0.037 & - & 1.12 & - & $(0.36 \pm 0.08)$ & $(0.32 \pm 0.08)$ & - & - \\
\hline 333 & 0.037 & - & 1.12 & - & $(1.13 \pm 0.10)$ & $(1.01 \pm 0.10)$ & - & - \\
\hline 343 & 0.037 & - & 1.12 & - & $(2.92 \pm 0.06)$ & $(2.61 \pm 0.06)$ & - & - \\
\hline 353 & 0.037 & - & 1.12 & - & $(6.73 \pm 0.09)$ & $(6.01 \pm 0.09)$ & & - \\
\hline 363 & 0.037 & - & 1.12 & - & $(11.12 \pm 0.10)$ & $(9.93 \pm 0.10)$ & - & - \\
\hline 343 & 0.037 & - & - & 1.12 & $(2.42 \pm 0.07)$ & $(2.16 \pm 0.07)$ & - & - \\
\hline 353 & 0.037 & - & - & 1.12 & $(5.61 \pm 0.06)$ & $(5.01 \pm 0.06)$ & - & - \\
\hline 363 & 0.037 & - & - & 1.12 & $(9.27 \pm 0.08)$ & $(8.28 \pm 0.08)$ & - & - \\
\hline 343 & 0.037 & - & 0.76 & - & $(1.83 \pm 0.12)$ & $(2.41 \pm 0.12)$ & - & - \\
\hline 343 & 0.037 & - & 0.95 & - & $(2.35 \pm 0.05)$ & $(2.47 \pm 0.05)$ & - & - \\
\hline 343 & 0.037 & - & 1.33 & - & $(3.25 \pm 0.10)$ & $(2.44 \pm 0.10)$ & - & - \\
\hline 343 & 0.037 & - & 1.52 & - & $(3.73 \pm 0.10)$ & $(2.45 \pm 0.10)$ & - & - \\
\hline 323 & - & 0.037 & 1.12 & - & - & & $(0.12 \pm 0.10)$ & $(0.11 \pm 0.10)$ \\
\hline 333 & - & 0.037 & 1.12 & - & - & - & $(0.35 \pm 0.13)$ & $(0.31 \pm 0.13)$ \\
\hline 343 & - & 0.037 & 1.12 & - & - & - & $(1.03 \pm 0.07)$ & $(0.92 \pm 0.07)$ \\
\hline 353 & - & 0.037 & 1.12 & - & - & & $(2.04 \pm 0.10)$ & $(1.82 \pm 0.10)$ \\
\hline 363 & - & 0.037 & 1.12 & - & - & - & $(4.49 \pm 0.10)$ & $(3.58 \pm 0.10)$ \\
\hline 343 & - & 0.037 & - & 1.12 & - & - & $(0.78 \pm 0.10)$ & $(0.69 \pm 0.10)$ \\
\hline 353 & - & 0.037 & - & 1.12 & - & - & $(1.58 \pm 0.08)$ & $(1.41 \pm 0.08)$ \\
\hline 363 & - & 0.037 & - & 1.12 & - & - & $(3.41 \pm 0.12)$ & $(3.04 \pm 0.12)$ \\
\hline 343 & - & 0.037 & 0.76 & - & - & - & $(0.68 \pm 0.07)$ & $(0.89 \pm 0.07)$ \\
\hline 343 & - & 0.037 & 0.95 & - & - & - & $(0.82 \pm 0.10)$ & $(0.86 \pm 0.10)$ \\
\hline 343 & - & 0.037 & 1.33 & - & - & - & $(1.18 \pm 0.09)$ & $(0.88 \pm 0.09)$ \\
\hline 343 & - & 0.037 & 1.52 & - & - & - & $(1.41 \pm 0.07)$ & $(0.93 \pm 0.07)$ \\
\hline
\end{tabular}

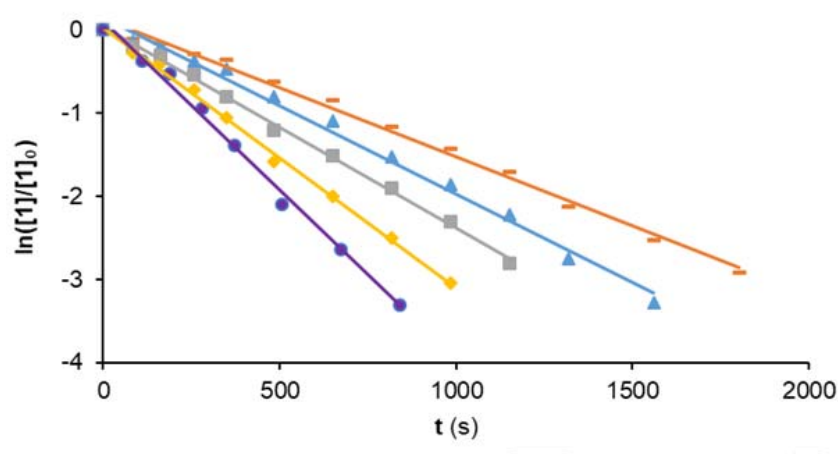

Figure 2. Graphical representation of eq 1 for the different concentrations of HBpin employed at 353 K. $0.747 \mathrm{M}$ (orange -); $0.933 \mathrm{M}$ (blue $\mathbf{\Delta}$ ); $1.120 \mathrm{M}$

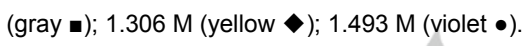

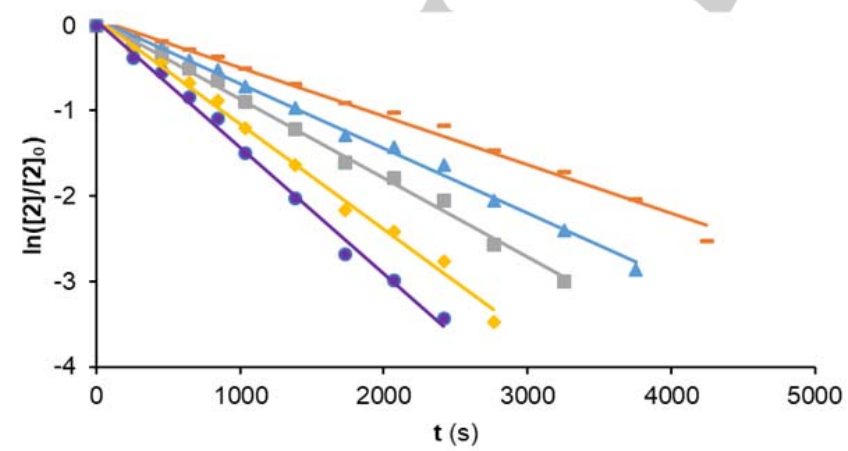

Figure 3 Graphical representation of eq 2 for the different concentrations of HBpin employed at 353 K. $0.748 \mathrm{M}$ (orange -); $0.934 \mathrm{M}$ (blue $\boldsymbol{\Delta}$ ); $1.122 \mathrm{M}$ (gray $\mathbf{~ ) ; ~} 1.309 \mathrm{M}$ (yellow $\bullet$ ); $1.496 \mathrm{M}$ (violet $\bullet$ ).
Plots of $\ln (-\mathrm{d}[1] / \mathrm{d} t)$ versus $\ln [\mathrm{HBpin}]$ and $\ln (-\mathrm{d}[2] / \mathrm{d} t)$ versus In[HBpin] yield straight lines of slopes 1.03 and 1.05, respectively (Figures S1 and S2 in the Supporting Information), which are consistent with reactions of first order also in HBpin concentration. Thus the rate laws are described by eqs 3-6

$$
\begin{gathered}
\frac{d[\mathbf{2}]}{d t}=-\frac{d[\mathbf{1}]}{d t}=k_{1}[\mathbf{1}][\text { HBpin }] \\
k_{1} \text { [HBpin] }=k_{1}^{\text {obs }}
\end{gathered}
$$

$$
\frac{d[3]}{d t}=-\frac{d[2]}{d t}=k_{2}[2][\text { HBpin }]
$$

where

$$
k_{2}[\text { HBpin }]=k_{2}^{o b s}
$$

Plots of $k_{1}{ }^{\text {obs }}$ versus [HBpin] (Figure 4 ) and $k_{2}{ }^{\text {obs }}$ versus [HBpin] (Figure 5) provide the rate constants $k_{1}$ and $k_{2}$ for each temperature (Table 1). The activation parameters calculated from the respective Eyring analysis (Figures 6 and 7) are $\Delta H^{\ddagger}=$ $19.5 \pm 1.2 \mathrm{kcal} \mathrm{mol}^{-1}$ and $\Delta S^{\ddagger}=-13.8 \pm 3.5 \mathrm{cal} \mathrm{K}^{-1} \mathrm{~mol}^{-1}$ for the transformation from 1 to 2 and $\Delta H^{\ddagger}=20.0 \pm 1.2 \mathrm{kcal} \mathrm{mol}^{-1}$ and $\Delta S^{\ddagger}=-14.3 \pm 3.7 \mathrm{cal} \mathrm{K}^{-1} \mathrm{~mol}^{-1}$ for the transformation from 2 into 3. These values yield activation energies $\Delta G_{1}{ }^{\ddagger}$ and $\Delta G_{2}{ }^{\ddagger}$ at $298 \mathrm{~K}$ of $23.6 \pm 2.2$ and $24.3 \pm 2.5 \mathrm{kcal} \mathrm{mol}^{-1}$, respectively. Table 1 also contains the values of the first order rate constants $k_{1}{ }^{\text {obs-d }}$ and $k_{2}{ }^{\text {obs- } d}$ obtained for the reactions with DBpin. The ratios 
$k_{1}{ }^{\text {obs }} / k_{1}{ }^{\text {obs- } d}$ and $k_{2}{ }^{\text {obs }} / k_{2}{ }^{\text {obs-d }}$ give secondary isotope effects ${ }^{[33]}$ of $1.2 \pm 0.1$ and $1.3 \pm 0.1$, respectively.

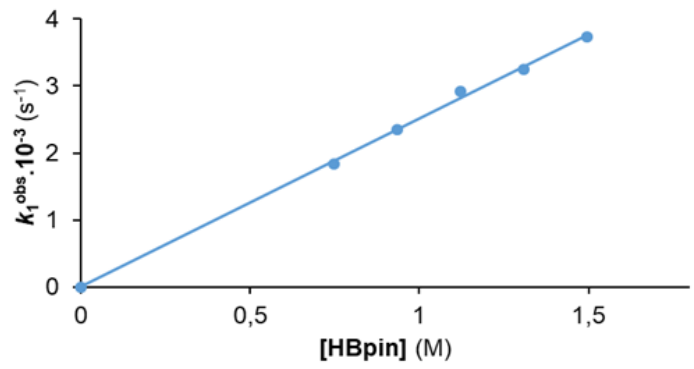

Figure 4. Plot of $k_{1}{ }^{\text {obs }}$ versus [HBpin].

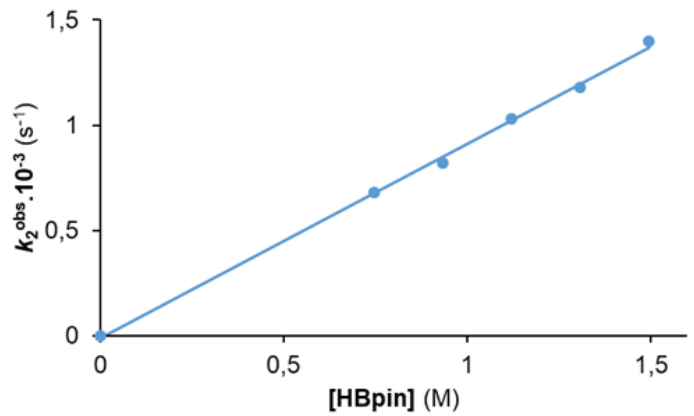

Figure 5. Plot of $k_{2}{ }^{\mathrm{obs}}$ versus [HBpin].

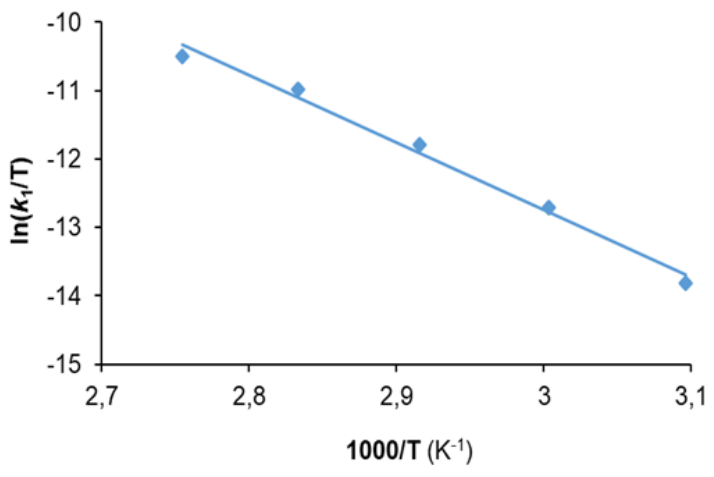

Figure 6. Eyring plot for the transformation of 1 into 2.

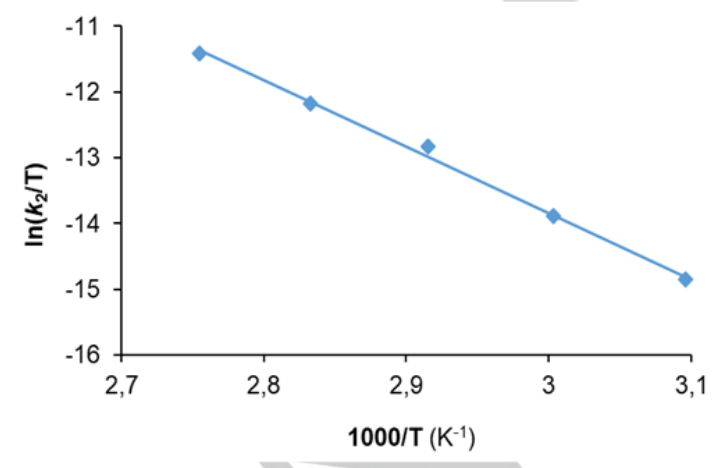

Figure 7. Eyring plot for the transformation of 2 into 3.

The values significantly negative of the activation entropies indicate highly ordered transition states in the rate determining steps of the activations. This suggests the presence of the borane in them, in a consistent manner with the first order of the reactions rate with regard to the HBpin concentration. However, the values of the secondary isotope effects reveal that the borane has not a direct participation; i. e., neither the cleavage of the $\mathrm{B}-\mathrm{H}$ bond nor the formation of a bond with the hydrogen originally on boron is likely occurring in the rate-determining transition state So, once rejected the reductive elimination of $\mathrm{H}_{2}$ (according to Scheme 5) and given the saturated character of 1 and 2, it appears reasonable to think that the first steps of both activations are the addition of the borane to a hydride to form saturated $\mathrm{K}^{1}$-dihydrideborate intermediates (A in Scheme 6 ), According to the exact $1: 1$ distribution of $\mathrm{H}$ - and D-containing products in the reactions with DBpin, the free and coordinated hydrogen atoms of this ligand should be involved in a fast position exchange process. Intermediate $\mathbf{A}$ would subsequently dissociate the oxygen atom of the diphosphine to afford $\mathbf{B}$, in the rate determining steps. In this way, the coordination of the free $\mathrm{B}-\mathrm{H}$ bond of the dihydrideborate of the latter could give the $\operatorname{Ir}\left(\mathrm{n}^{2}-\right.$ $\mathrm{HB}$ ) intermediates $\mathbf{C}$ via $\mathrm{K}^{2}$-dihydrideborate and bis(elongated sigma)-dihydroborate species. ${ }^{[22 \mathrm{k}]}$ Once coordinated the $\mathrm{B}-\mathrm{H}$ bond, its oxidative addition and subsequent reductive hydrogen elimination could generate $\mathbf{D}$, which should lead to $\mathbf{2}$ and $\mathbf{3}$ by the re-coordination of the oxygen atom of the diphosphine.

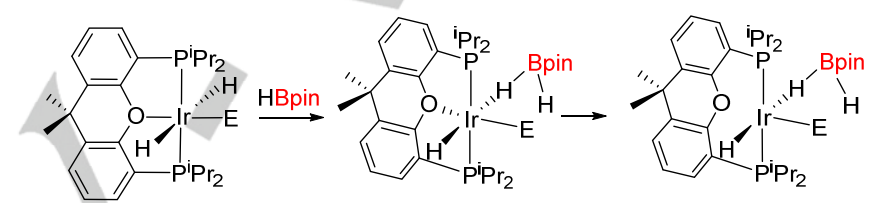

$E=H(1), B p i n(2)$

A

B

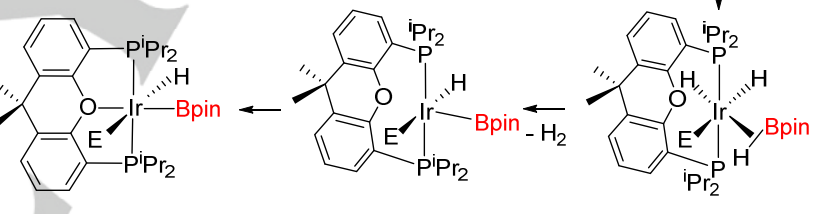

$E=H(2), B p i n(3)$

D

C

Scheme 6. Mechanism proposed for the B-H bond activation

Reactions with Benzene. The hydride-bisboryl complex 3 reacts with the solvent in benzene solution to give pinB-Ph and the dihydride-boryl derivative $2\left(k_{3}\right)$, which also activates the solvent to afford a second molecule of pinB-Ph and the trihydride 1 ( $k_{4}$ in Scheme 7).

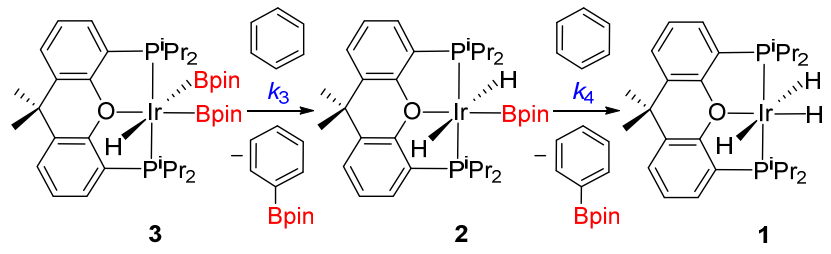

Scheme 7. Activation of benzene.

Both transformations were independently followed by ${ }^{31} \mathrm{P}\left\{{ }^{1} \mathrm{H}\right\}$ NMR spectroscopy as a function of the time between 333 and $353 \mathrm{~K}$. The decreases of 3 and 2 with the respective increases of 2 and 1 (Figures S3 and S4 in the Supporting Information) are exponential functions of the time, fitting to expressions of first-order: 


$$
\ln \frac{[3]}{[3]_{0}}=-k_{3} t
$$

and

$$
\ln \frac{[2]}{[2]_{0}}=-k_{4} t
$$

where $[3]_{0}$ and [2] $]_{0}$ are the initial concentrations of $\mathbf{3}$ and 2, respectively, and [3] and [2] are the concentrations in the time $t$. The obtained values for $k_{3}$ and $k_{4}$ are collected in Table 2 . The activation parameters obtained from the respective Eyring analysis (Figures 8 and 9) are $\Delta H^{\ddagger}=19.3 \pm 2.3 \mathrm{kcal} \mathrm{mol}^{-1}$ and $\Delta S^{\ddagger}=-19.2 \pm 5.1 \mathrm{cal} \mathrm{K}^{-1} \mathrm{~mol}^{-1}$ for the transformation from 3 to 2 and $\Delta H^{\ddagger}=22.5 \pm 2.5 \mathrm{kcal} \mathrm{mol}^{-1}$ and $\Delta S^{\ddagger}=-12.9 \pm 5.4 \mathrm{cal} \mathrm{K}^{-1}$ $\mathrm{mol}^{-1}$ for the transformation from 2 to 1 . These values yield activation energies $\Delta G_{3}^{\ddagger}$ and $\Delta G_{4}^{\ddagger}$ at $298 \mathrm{~K}$ of $25.0 \pm 3.5$ and $26.3 \pm 3.8 \mathrm{kcal} \mathrm{mol}^{-1}$, respectively.

Table 2. Rate Constants for the transformations of $\mathbf{3}$ into $\mathbf{2}\left(k_{3}\right)$ and of $\mathbf{2}$ into $\mathbf{1}$

\begin{tabular}{|c|c|c|c|c|c|}
\hline $\begin{array}{c}T \\
(K)\end{array}$ & $\begin{array}{l}{[3]_{\circ}} \\
(\mathrm{M})\end{array}$ & $\begin{array}{l}{[2]_{0}} \\
(\mathrm{M})\end{array}$ & Arene & $\begin{array}{c}k_{3} \times 10^{-4} \\
\left(\mathrm{~s}^{-1}\right)\end{array}$ & $\begin{array}{c}k_{4} \times 10^{-4} \\
\left(\mathrm{~s}^{-1}\right)\end{array}$ \\
\hline 333 & 0.037 & - & $\mathrm{C}_{6} \mathrm{H}_{6}$ & $(0.95 \pm 0.10)$ & - \\
\hline 338 & 0.037 & - & $\mathrm{C}_{6} \mathrm{H}_{6}$ & $(1.35 \pm 0.08)$ & - \\
\hline 343 & 0.037 & - & $\mathrm{C}_{6} \mathrm{H}_{6}$ & $(2.34 \pm 0.07)$ & - \\
\hline 348 & 0.037 & - & $\mathrm{C}_{6} \mathrm{H}_{6}$ & $(3.55 \pm 0.10)$ & - \\
\hline 353 & 0.037 & - & $\mathrm{C}_{6} \mathrm{H}_{6}$ & $(4.95 \pm 0.10)$ & - \\
\hline 343 & 0.037 & - & $\mathrm{C}_{6} \mathrm{D}_{6}$ & $(0.75 \pm 0.08)$ & - \\
\hline 343 & 0.037 & - & $\mathrm{C}_{6} \mathrm{H}_{4} \mathrm{Cl}_{2}$ & $(3.74 \pm 0.08)$ & - \\
\hline 343 & 0.037 & - & $\mathrm{C}_{6} \mathrm{H}_{4} \mathrm{Me}_{2}$ & $(1.94 \pm 0.06)$ & - \\
\hline 333 & - & 0.037 & $\mathrm{C}_{6} \mathrm{H}_{6}$ & - & $(0.17 \pm 0.06)$ \\
\hline 338 & - & 0.037 & $\mathrm{C}_{6} \mathrm{H}_{6}$ & - & $(0.31 \pm 0.09)$ \\
\hline 343 & - & 0.037 & $\mathrm{C}_{6} \mathrm{H}_{6}$ & - & $(0.52 \pm 0.06)$ \\
\hline 348 & - & 0.037 & $\mathrm{C}_{6} \mathrm{H}_{6}$ & - & $(0.81 \pm 0.10)$ \\
\hline 353 & - & 0.037 & $\mathrm{C}_{6} \mathrm{H}_{6}$ & - & $(1.26 \pm 0.09)$ \\
\hline 343 & - & 0.037 & $\mathrm{C}_{6} \mathrm{D}_{6}$ & - & $(0.18 \pm 0.07)$ \\
\hline 343 & - & 0.037 & $\mathrm{C}_{6} \mathrm{H}_{4} \mathrm{Cl}_{2}$ & - & $(0.73 \pm 0.10)$ \\
\hline 343 & - & 0.037 & $\mathrm{C}_{6} \mathrm{H}_{4} \mathrm{Me}_{2}$ & - & $(0.40 \pm 0.09)$ \\
\hline
\end{tabular}
$\left(k_{4}\right)$ and $k_{2}$ calculated according to eqs 7 and 8 , respectively

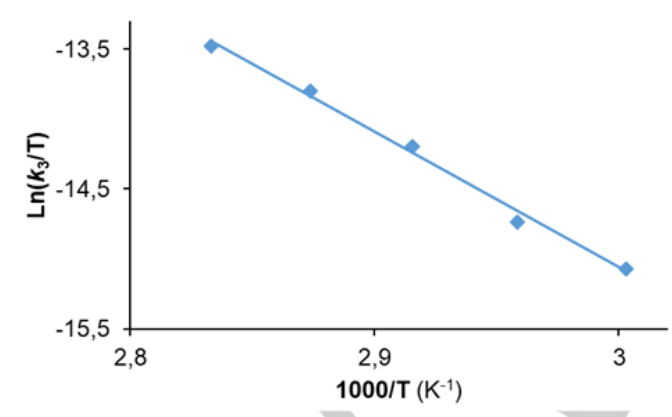

Figure 8. Eyring plot for the transformation of $\mathbf{3}$ into $\mathbf{2}$.

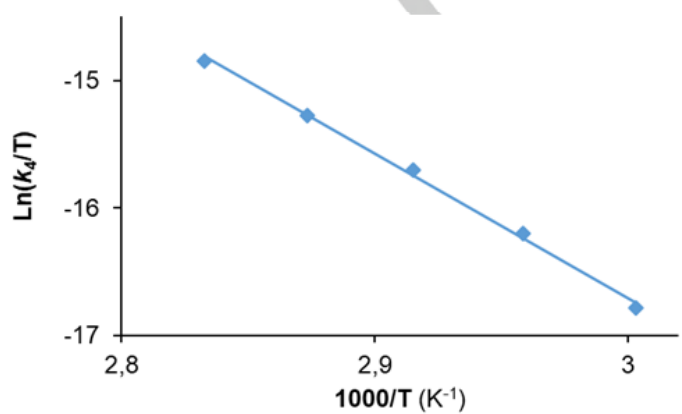

Figure 9. Eyring plot for the transformation of 2 into 1.

The rates of the reactions of $\mathbf{3}$ and $\mathbf{2}$ with $\left[\mathrm{D}_{6}\right]$ benzene are significantly slower than those with benzene. The ratios $k_{3} / k_{3-d}$ and $k_{4} / k_{4-\mathrm{d}}$ give primary isotope effects of $3.1 \pm 0.1$ and $2.8 \pm 0.1$, respectively, which support the rupture of the aromatic $\mathrm{C}-\mathrm{H}$ bond as the rate determining step of the functionalization. This is consistent with the strongly negative values of the activation entropies, which suggest the coordination of the activated $\mathrm{C}-\mathrm{H}$ bond to the metal center in the transition state for the rupture and therefore the dissociation of the oxygen atom of the diphosphine before the rate determining step, in contrast to the previous reactions involving $\mathrm{B}-\mathrm{H}$ bond activation.

The behavior of 2 and $\mathbf{3}$ in 1,3-dichlorobenzene $\left(k_{3}{ }^{\mathrm{Cl} 2}\right.$ and $k_{4}{ }^{\mathrm{Cl}}$ ) and meta-xylene $\left(k_{3}{ }^{\mathrm{Me} 2}\right.$ and $k_{4}{ }^{\mathrm{Me} 2}$ ) was also studied in order to gain additional information on the $\mathrm{C}-\mathrm{H}$ rupture. Both solvents react with the boryl complexes to form meta-boryl-substituted products, as expected for a steric control of the regioselectivity of the arene functionalization (Scheme 8). The rate of the reactions decreases in the sequence 1,3-dichlorobenzene > benzene > meta-xylene; i.e., electron deficient rings are borylated faster than electron rich rings. The ratios $k_{3}{ }^{\mathrm{Cl}} / k_{3}$, $k_{4}{ }^{\mathrm{Cl} 2} / k_{4}, k_{3}{ }^{\mathrm{Me} 2} / k_{3}$, and $k_{4}{ }^{\mathrm{Me} 2} / k_{4}$ are $1.6,1.4,0.83$, and 0.77 , respectively. The increase of the reaction rate with the decrease of the electron density of the ring is consistent with a homolytic cleavage of the $\mathrm{C}-\mathrm{H}$ bond, resulting from the nucleophilic attack of the metal center. The cleavage should afford $\operatorname{aryl}-\operatorname{Ir}(\mathrm{V})$ intermediates.
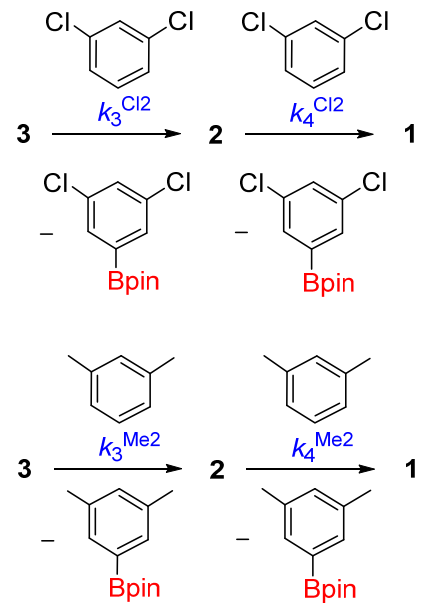

Scheme 8. Reactions with 1,3-dichlorobenzene and meta-xylene.

The results of the previously mentioned stoichiometric reactions of complexes $\mathbf{3}$ and $\mathbf{2}$ with arenes can be jointly rationalized according to Scheme 9 . The coordination of the organic substrate to the metal center of the unsaturated intermediates D shown in Scheme 6 should give the $\sigma$ derivatives $\mathbf{E}$, which would evolve to the $\operatorname{Ir}(\mathrm{V})$-intermediates $\mathbf{F}$ by oxidative addition of the coordinated $\mathrm{C}-\mathrm{H}$ bond of the arene. Thus, the rapid reductive elimination of aryl-Bpin could yield the metal products

Catalytic Borylation of Arenes Promoted by 2. Reactions shown in Schemes 4 and 7 define two cycles for the formation of $\mathrm{PhBpin}$ by direct $\mathrm{C}-\mathrm{H}$ borylation of benzene ( $\mathrm{A}$ and $\mathrm{B}$ in Scheme $10)$, where the dihydride-boryl complex 2 is a common species. 
The rate determining step in both cycles is the cleavage of $\mathrm{C}-\mathrm{H}$ bond of the arene, being favored in cycle $B$ with regard to cycle A.

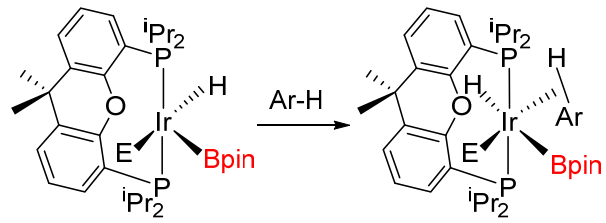

D

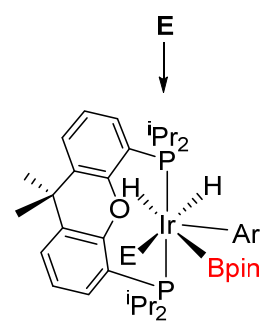

$E=$ Bpin (2), H (1)

$\mathbf{F}$

Scheme 9. Mechanistic proposal for the $\mathrm{C}-\mathrm{H}$ bond activation of arenes.

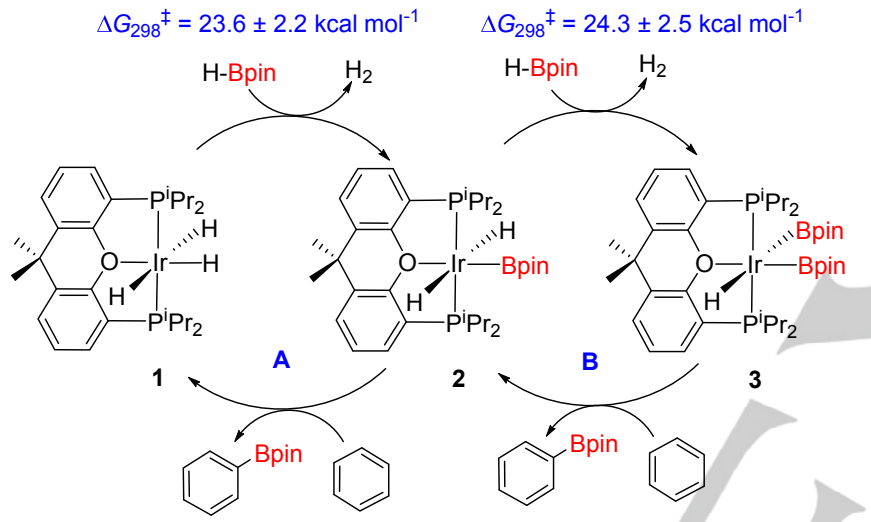

$\Delta G_{298}{ }^{\ddagger}=26.3 \pm 3.8 \mathrm{kcal} \mathrm{mol}^{-1}$

$\Delta G_{298}{ }^{\ddagger}=25.0 \pm 3.5 \mathrm{kcal} \mathrm{mol}^{-1}$

Scheme 10. Mechanism of the borylation of arenes catalyzed by $\mathbf{1}, 2$, and 3 .

Dihydride-boryl complex $\mathbf{2}$ efficiently promotes the borylation of benzene, as expected from the cycles shown in Scheme 10, with both HBpin and $\mathrm{B}_{2} \mathrm{pin}_{2}$, in the absence and in the presence of cyclohexene as hydrogen acceptor (Table 3 ). Because the rate determining step in both cycles is the rupture of a $\mathrm{C}-\mathrm{H}$ bond of the arene, the same arene was used as solvent, at $110{ }^{\circ} \mathrm{C}$. Under these conditions the borane is better borylating reagent than the diborane. The olefin also improves the arene borylation; the reason is thermodynamic, since the transformations shown in Scheme 4 are equilibria shifted towards the right, which change of direction under excess of molecular hydrogen. The trihydride complex 1 removes the generated $\mathrm{H}_{2}$ by catalyzing the cyclohexene hydrogenation. By using a $\mathrm{C}_{6} \mathrm{H}_{10} / \mathrm{HBpin}$ ratio of $1.0, \mathrm{PhBpin}$ was isolated in $90 \%$ yield after $18 \mathrm{~h}$.

Complex 2 also catalyzes the direct $\mathrm{C}-\mathrm{H}$ borylation of mono-, di-, and trisubstituted benzenes as well as furan. It tolerates a variety of functionalities, including $\mathrm{CH}_{3}, \mathrm{OCH}_{3}, \mathrm{CF}_{3}, \mathrm{~F}$, $\mathrm{Cl}$, and $\mathrm{Br}$. Under the conditions used for the borylation of benzene, borylated products were isolated in almost quantitative yields after $18 \mathrm{~h}$, in all the cases, independently of the electron donating or electron withdrawing nature of the substituents (Scheme 11). In agreement with classical $\operatorname{Ir}(B \text { pin })_{3} L_{2}$ catalysts, ${ }^{[12,13]}$ the selectivity of the functionalization is governed by steric factors, which are slightly modulated by electronic influence of the substituents on the aromatic ring, as expected for reactions controlled by the kinetic of $\mathrm{C}-\mathrm{H}$ bond activation of the arene. Thus, the borylation proceeds with high selectivity for functionalization of the least sterically hindered $\mathrm{C}-\mathrm{H}$ bond of the aromatic ring. Toluene and anisole give meta- and parasubstituted products in a 60:40 molar ratio. Electron withdrawing groups such as $\mathrm{CF}_{3}, \mathrm{Cl}$, and $\mathrm{Br}$ increase the meta:para ratio (70:30, 70:30, and 85:15, respectively). 1,3-Disubstituted benzenes undergo exclusively borylation at position meta with regard to both groups, in agreement with the stoichiometric borylations shown in Scheme 8, whereas 1,2,3-trichlorobenzene and furan give the respective 3,4,5-trichlorophenyl- and 2-furanboryl esters.

Table 3. Optimization of the reaction conditions for the borylation of benzene catalyzed by complex 2 . ${ }^{\text {a] }}$

\begin{tabular}{cccccc}
\hline Run & Time (h) & $\begin{array}{c}\text { Boron } \\
\text { source }\end{array}$ & $\begin{array}{c}\text { Cyclohe- } \\
\text { xene }\end{array}$ & $\begin{array}{c}\text { Catalyst } \\
\text { (mol\%) }\end{array}$ & $\begin{array}{c}\text { Yield } \\
\text { (\%) }\end{array}$ \\
\hline 1 & 24 & HBpin & yes & 5 & 100 \\
2 & 24 & HBpin & no & 5 & 47 \\
3 & 24 & B $_{2}$ pin $_{2}$ & no & 5 & 19 \\
4 & 24 & B $_{2}$ Pin $_{2}$ & yes & 5 & 52 \\
5 & 20 & HBpin & yes & 5 & 100 \\
6 & 18 & HBpin & yes & 5 & 94 \\
7 & 18 & HBpin & yes & 2.5 & 58 \\
8 & 18 & HBpin & yes & 1 & 21 \\
\hline
\end{tabular}

[a] $1 \mathrm{~mL}$ of benzene, $110{ }^{\circ} \mathrm{C}, 0.20 \mathrm{mmol}$ of HBpin or $0.10 \mathrm{mmol}^{\circ} \mathrm{B}_{2} \mathrm{pin}_{2}, 0.2$ $\mathrm{mmol}$ of cyclohexene. Yields were determined by ${ }^{1} \mathrm{H}$ NMR spectroscopy

The smaller size and higher electronegativity of the fluorine atom has a marked influence on the selectivity. In contrast to $\mathrm{Cl}$ and $\mathrm{Br}$, the fluorinated arenes give mixtures containing a high proportion of compounds bearing the Bpin group disposed ortho to fluorine. Thus, fluorobenzene and 1,3-difluorobenzene yield mixtures of the three possible isomers, whereas 1-chloro-3fluorobenzene affords two products: the arene with the Bpin group disposed ortho to $\mathrm{F}(30 \%)$ and that bearing the Bpin group disposed meta to both halides $(70 \%)$. The reason of this behavior appears to be related to an increase of the B-C bond energy with the ortho-fluorine substitution. ${ }^{[2]}$ The effect has been explained in terms of an increment of the ionic component of the bond by inductive effect of the ortho-fluorine atom. ${ }^{[34]}$

We have also analyzed the borylation of $\left[D_{8}\right]$ toluene and $\left[D_{5}\right]$ bromobenzene (Scheme 12) in order to know the influence of the isotopic substitution on the selectivity of the functionalization. In both cases as well as for $\left[D_{6}\right]$ benzene, a slight decrease of the reaction yield after $18 \mathrm{~h}$ was observed, which may be related to the decrease of the reaction rate as a result of the increase of the strength of the activated bond of the arene. The borylation of $\left[D_{8}\right]$ toluene slightly increases the selectivity at the meta position (65:35 versus 60:40). However, the borylation of $\left[D_{5}\right]$ bromobenzene displays a significant reduction of the functionalization of the meta position with regard to bromobenzene $(50: 50$ versus $85: 15)$, leading to an equimolecular mixture of the meta and para isomers. This suggests that the deuteration of monosubstituted arenes with electron donating groups does not significantly affect the ratio between the strength of the bonds situated in meta and para 

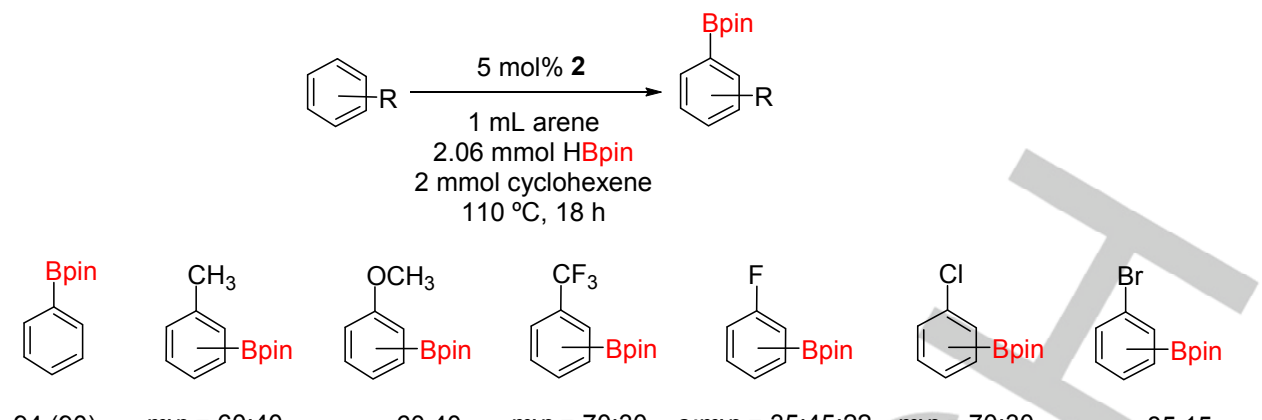

94 (90) $\quad m: p=60: 40 \quad m: p=60: 40 \quad m: p=70: 30 \quad$ o:m:p=35:45:22 $\quad m: p=70: 30 \quad m: p=85: 15$

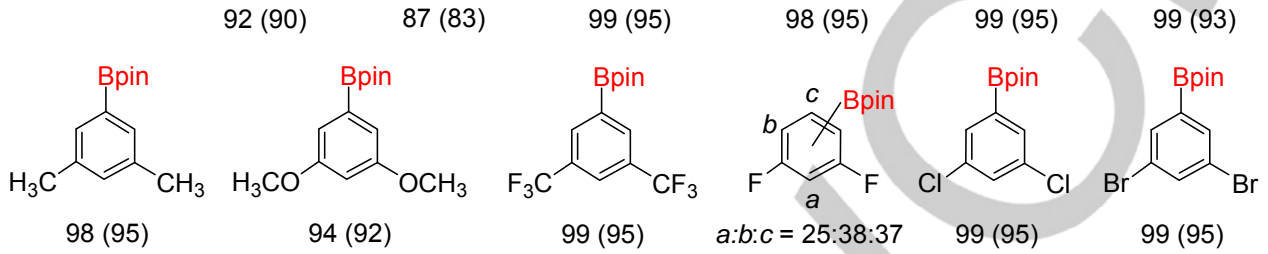

$98(95)$<smiles>Cc1cc(Cl)cc(Br)c1</smiles>

$99(95)$<smiles>COc1cc(Br)cc(C(F)(F)F)c1</smiles>

$97(95)$<smiles>Fc1ccc(Br)c(Br)c1</smiles>

$a: b=30: 70$ $99(95)$
(93)

Scheme 11. Borylation of arenes (isolated yields in parentheses).

with regard to the substituent, whereas the deuteration of monosubstituted arenes with electron withdrawing groups increases the strength of the bond in meta position with regard to that situated at para.

$$
\text { (C) }
$$

89

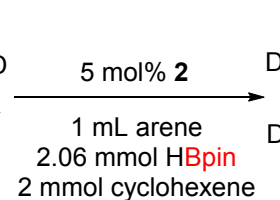

$110^{\circ} \mathrm{C}, 18 \mathrm{~h}$

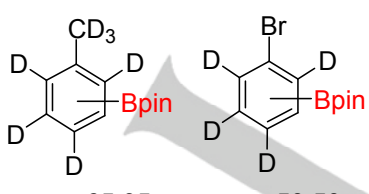

$m: p=65: 35$

85
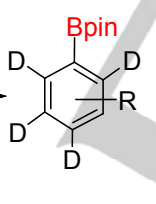

$$
\text { Bpin }
$$

87
Scheme 12. Borylation of deuterated arenes.

Both complexes 2 and $\mathbf{3}$ promote the direct $\mathrm{C}-\mathrm{H}$ borylation of arenes and each boryl derivative generates a catalytic cycle. In addition, it should be noted that complex 3 is the $x a n t\left(\mathrm{P}^{\mathrm{i}} \mathrm{Pr}_{2}\right)_{2}$ counterpart of intermediates $\mathrm{IrH}(\mathrm{Bpin})_{2} \mathrm{~L}_{2}$ shown in Scheme 1. So, it appears to be reasonable to think that the direct $\mathrm{C}-\mathrm{H}$ borylation of arenes catalyzed by $\operatorname{Ir}(\text { Bpin })_{3} \mathrm{~L}_{2}$ takes place through a mechanism more complex than that shown in Scheme 1. According to our observations, that mechanism should be defined by three cycles, involving complexes $\operatorname{Ir}(B p i n)_{3} L_{2}$, $\operatorname{IrH}(\text { Bpin })_{2} \mathrm{~L}_{2}$, and $\mathrm{IrH}_{2}$ (Bpin) $\mathrm{L}_{2}$ as key intermediates, although the elemental steps within each cycle should be similar to those shown in Scheme 1.

\section{Conclusion}

The kinetic study of the $\mathrm{B}-\mathrm{H}$ bond activation of pinacolborane promoted by the trihydride $\operatorname{IrH}_{3}\left\{\mathrm{~K}^{3}-\mathrm{P}, \mathrm{O}, \mathrm{P}-\right.$ [xant $\left.\left.\left(\mathrm{P}^{\mathrm{i}} \mathrm{Pr}_{2}\right)_{2}\right]\right\}$ (Scheme 4) and of the $\mathrm{C}-\mathrm{H}$ bond activation of benzene mediated by the resulting hydride-boryl derivatives $\operatorname{IrH}_{2}(\mathrm{Bpin})\left\{\mathrm{K}^{3}-\mathrm{P}, \mathrm{O}, \mathrm{P}-\left[\mathrm{xant}\left(\mathrm{PiPr}_{2}\right)_{2}\right]\right\} \quad$ and $\operatorname{IrH}(\mathrm{Bpin})_{2}\left\{\mathrm{~K}^{3}-\mathrm{P}, \mathrm{O}, \mathrm{P}-\right.$ $\left.\left[\mathrm{xant}\left(\mathrm{P}^{\mathrm{i}} \mathrm{Pr}_{2}\right)_{2}\right]\right\} \quad$ (Scheme 7) has revealed that the three compounds are involved in two catalytic cycles for the direct $\mathrm{C}-\mathrm{H}$ borylation of arenes, which have the dihydride $\mathrm{IrH}_{2}($ Bpin $)\left\{\mathrm{K}^{3}\right.$ $\left.\mathrm{P}, \mathrm{O}, \mathrm{P}-\left[\mathrm{xant}\left(\mathrm{P}^{\mathrm{i}} \mathrm{Pr}_{2}\right)_{2}\right]\right\}$ as common intermediate (Scheme 10). The presence of basic hydride ligands in these saturated compounds facilitates the coordination of the $\mathrm{B}-\mathrm{H}$ bond of the borane to the metal center, since they can bind to the acidic boron center. The addition of the borane to one of the hydride ligands leads to $\mathrm{K}^{1}$ dihydrideborate intermediates, which dissociate the coordinated oxygen atom of the diphosphine and subsequently coordinate the free $\mathrm{B}-\mathrm{H}$ bond of the formed dihydrideborate group. Once coordinated the $\mathrm{B}-\mathrm{H}$ bond, its activation (Scheme 6 ) as well as the $\mathrm{C}-\mathrm{H}$ bond activation of the arene (Scheme 9) follow the usual procedure. The $\mathrm{C}-\mathrm{H}$ cleavage is the rate determining step for both cycles, being faster the $\mathrm{C}-\mathrm{H}$ oxidative addition to $\mathrm{IrH}(\mathrm{Bpin})_{2}\left\{\mathrm{~K}^{3}-\mathrm{P}, \mathrm{O}, \mathrm{P}-\left[\mathrm{xant}\left(\mathrm{P}^{\mathrm{i}} \mathrm{Pr}_{2}\right)_{2}\right]\right\}$ than to $\operatorname{IrH}_{2}(\mathrm{Bpin})\left\{\mathrm{K}^{3}-\mathrm{P}, \mathrm{O}, \mathrm{P}-\right.$ [xant $\left.\left.\left(\mathrm{P}^{\mathrm{i}} \mathrm{Pr}_{2}\right)_{2}\right]\right\}$. Complex $\operatorname{IrH}(\mathrm{Bpin})_{2}\left\{\mathrm{~K}^{3}-\mathrm{P}, \mathrm{O}, \mathrm{P}-\left[\mathrm{xant}\left(\mathrm{P}^{\mathrm{i}} \mathrm{Pr}_{2}\right)_{2}\right]\right\}$ is the xant $\left(\mathrm{P}^{\mathrm{i}} \mathrm{Pr}_{2}\right)_{2}$-counterpart of intermediates $\mathrm{IrH}(\mathrm{Bpin})_{2} \mathrm{~L}_{2}$ in the cycle generally proposed for the direct $\mathrm{C}-\mathrm{H}$ borylation of arenes in the presence of the classical $\operatorname{Ir}(\text { Bpin })_{3} \mathrm{~L}_{2}$ catalysts.

In summary, this study points out two subjects of interest: the hydrides are cooperative ligands in the $\mathrm{B}-\mathrm{H}$ bond activation reactions, since facilitate the coordination of the borane to the metal center and are therefore useful and desirable in the borylation catalysts along with monodentate boryl groups; and 
the catalytic $\mathrm{C}-\mathrm{H}$ borylation of arenes with boranes takes place through several cycles, which coexist. This is due to the presence of intermediates $L_{m} M\left(B R_{2}\right)_{n}$ and $L_{m} M H_{x}\left(B R_{2}\right)_{n-x}$, which are in equilibrium during the reaction. Each species of this class gives rise to a different catalytic cycle. All these cycle are formed by similar elemental steps.

\section{Experimental Section}

General information. All reactions were carried out with exclusion of air using Schlenk-tube techniques or in a drybox. Instrumental methods and $X$-ray details are given in the Supporting Information. In the NMR spectra the chemical shifts (in ppm) are referenced to residual solvent peaks $\left({ }^{1} \mathrm{H}\right.$, $\left.{ }^{13} \mathrm{C}\left\{{ }^{1} \mathrm{H}\right\}\right)$ or external $\left.\left.85 \% \mathrm{H}_{3} \mathrm{PO}_{4}\left({ }^{31} \mathrm{P}^{1}{ }^{1} \mathrm{H}\right\}\right), \mathrm{BF}_{3} \cdot \mathrm{OEt}_{2}\left({ }^{11} \mathrm{~B}^{1} \mathrm{H}\right\}\right)$, or $\mathrm{CFCl}_{3}$ $\left({ }^{19} \mathrm{~F}\right)$. Coupling constants $\mathrm{J}$ and $N\left(N=J_{\mathrm{P}-\mathrm{H}}+\mathrm{J}_{\mathrm{P}^{\prime}-\mathrm{H}}\right.$ for ${ }^{1} \mathrm{H}$ and $N=J_{\mathrm{P}-\mathrm{C}}+$ $J_{P^{\prime}-C}$ for $\left.{ }^{13} \mathrm{C}\left\{{ }^{1} \mathrm{H}\right\}\right)$ are given in hertz.

Improved method of synthesis of $\operatorname{IrH}_{3}\left\{\mathrm{~K}^{3}-\mathrm{P}, \mathrm{O}, \mathrm{P}-\left[\operatorname{xant}\left(\mathrm{P}^{\mathrm{i}} \mathrm{Pr}_{2}\right)_{2}\right]\right\}$ (1). A solution of IrHCl\{k $\left.{ }^{4}-\mathrm{C}, \mathrm{P}, \mathrm{O}, \mathrm{P}-\left[\mathrm{CH}_{2} \mathrm{CH}\left(\mathrm{CH}_{3}\right) \mathrm{P}(\mathrm{Pr}) \times \operatorname{xant}\left(\mathrm{P}^{\mathrm{i}} \mathrm{Pr} \mathrm{r}_{2}\right)\right]\right\}(200 \mathrm{mg}, 0.3$ $\mathrm{mmol})$ in toluene $(10 \mathrm{~mL})$ was cooled to $0{ }^{\circ} \mathrm{C}$ and then $\mathrm{NaBH}_{4}(125 \mathrm{mg}$, $3.3 \mathrm{mmol})$ was added. Methanol $(2 \mathrm{~mL})$ was added dropwise to the resulting suspension. After $15 \mathrm{~min}$, the resulting yellowish suspension was evaporated to dryness to afford a pale yellow residue. The addition of toluene afforded a pale yellow suspension, which was filtered through Celite to remove the sodium salts. The solution thus obtained was evaporated to dryness to afford a yellow residue. Addition of cold methanol $\left(-78^{\circ} \mathrm{C}\right)$ afforded a white solid, which was washed with further portions of cold methanol $(3 \times 0.3 \mathrm{~mL})$. Yield: $125 \mathrm{mg}(65 \%)$. NMR data agree with those reported previously. ${ }^{[22]}$

Reaction of $\operatorname{IrH}_{3}\left\{\mathrm{~K}^{3}-\mathrm{P}, \mathrm{O}, \mathrm{P}-\left[\mathrm{xant}\left(\mathrm{P}^{\mathrm{i}} \mathrm{Pr}_{2}\right)_{2}\right]\right\}$ (1) with HBpin: Preparation of $\mathrm{IrH}_{2}(\mathrm{Bpin})\left\{\mathrm{K}^{3}-\mathrm{P}, \mathrm{O}, \mathrm{P}-\left[\mathrm{xant}\left(\mathrm{P}^{\mathrm{i}} \mathrm{Pr}_{2}\right)_{2}\right]\right\}$ (2). A solution of $1(100 \mathrm{mg}, 0.16$ $\mathrm{mmol})$ in toluene $(3 \mathrm{~mL})$ was treated with HBpin $(24 \mu \mathrm{L}, 0.16 \mathrm{mmol})$ and the resulting mixture was stirred at room temperature for $8 \mathrm{~h}$. After this time, the yellowish solution was evaporated to dryness to afford a yellow residue. Pentane was added to afford a white solid, which was washed with pentane $(2 \times 1 \mathrm{~mL})$ and dried in vacuo. Yield: $72 \mathrm{mg}(60 \%)$. Anal. Calcd. for $\mathrm{C}_{33} \mathrm{H}_{54} \mathrm{BlrO}_{3} \mathrm{P}_{2}$ : C, 51.89; $\mathrm{H}, 7.13$. Found: $\mathrm{C}, 51.45 ; \mathrm{H}, 6.90$. HRMS (electrospray, $\mathrm{m} / \mathrm{z}$ ): calcd. for $\mathrm{C}_{33} \mathrm{H}_{53} \mathrm{BlrO}_{3} \mathrm{P}_{2}[\mathrm{M}-\mathrm{H}]^{+} 763.3194$; found 763.3194. IR $\left(\mathrm{cm}^{-1}\right)$ : v(Ir-H) $1743(\mathrm{w}), \mathrm{v}(\mathrm{C}-\mathrm{O}-\mathrm{C}) 1111(\mathrm{~m}) .{ }^{1} \mathrm{H}$ NMR (300.13 MHz, [ $\left.\mathrm{D}_{6}\right]$ benzene, $\left.298 \mathrm{~K}\right): \delta 7.32(\mathrm{~m}, 2 \mathrm{H}, \mathrm{CH}$-arom), $6.90(\mathrm{~m}$, $2 \mathrm{H}, \mathrm{CH}$-arom), $6.84\left(\mathrm{t},{ }^{3} \mathrm{~J}_{\mathrm{H}-\mathrm{H}}=7.5,2 \mathrm{H}, \mathrm{CH}\right.$-arom $), 2.58(\mathrm{~m}, 4 \mathrm{H}$, $\left.\mathrm{PCH}\left(\mathrm{CH}_{3}\right)_{2}\right), 1.64\left(\mathrm{dvt},{ }^{3} \mathrm{~J}_{\mathrm{H}-\mathrm{H}}=7.5, \mathrm{~N}=16.2,12 \mathrm{H}, \mathrm{PCH}\left(\mathrm{CH}_{3}\right)_{2}\right), 1.22(\mathrm{~s}$, $12 \mathrm{H}, \mathrm{CH}_{3}$ Bpin), 1.23 (dvt, $\left.{ }^{3} \mathrm{~J}_{\mathrm{H}-\mathrm{H}}=6.9, N=14.4,12 \mathrm{H}, \mathrm{PCH}\left(\mathrm{CH}_{3}\right)_{2}\right), 1.12$ (s, 6H, $\left.\mathrm{CH}_{3}\right),-6.11\left(\mathrm{t},{ }^{2} \mathrm{~J}_{\mathrm{H}-\mathrm{P}}=17.5,2 \mathrm{H}, \mathrm{Ir}-\mathrm{H}\right) .{ }^{13} \mathrm{C}\left\{{ }^{1} \mathrm{H}\right\}$-apt NMR $(75.47$ $\mathrm{MHz}$, [D6]benzene, $298 \mathrm{~K}$ ): $\delta 155.0$ (vt, $N=11.5$, Carom), 130.5 (vt, $N=$ 4.7, Carom), 130.2 (s, CH-arom), 128.9 (vt, $N=28.8$, Carom), 127.1 (s, $\mathrm{CH}$-arom), 124.3 (vt, $N=5.1, \mathrm{CH}$-arom), 80.3 (s, C Bpin), 33.8 (s, $\left.\mathrm{C}\left(\mathrm{CH}_{3}\right)_{2}\right), 32.3\left(\mathrm{~s}, \mathrm{C}\left(\mathrm{CH}_{3}\right)_{2}\right), 27.6$ (vt, $\left.\mathrm{N}=30.4, \mathrm{PCH}\left(\mathrm{CH}_{3}\right)_{2}\right), 25.3\left(\mathrm{~s}, \mathrm{CH}_{3}\right.$ Bpin), 20.0 (vt, $\left.N=6.5, \mathrm{PCH}\left(\mathrm{CH}_{3}\right)_{2}\right), 19.3\left(\mathrm{~s}, \mathrm{PCH}\left(\mathrm{CH}_{3}\right)_{2}\right) .{ }^{31} \mathrm{P}\left\{{ }^{1} \mathrm{H}\right\} \mathrm{NMR}$ $\left(121.49 \mathrm{MHz}\right.$, [ $\left.\mathrm{D}_{6}\right]$ benzene, $298 \mathrm{~K}$ ): $\delta 57.8$ (s, triplet under off-resonance decoupling conditions). ${ }^{11} \mathrm{~B}\left\{{ }^{1} \mathrm{H}\right\}$ NMR $\left(96.29 \mathrm{MHz},\left[\mathrm{D}_{6}\right]\right.$ benzene, $\left.298 \mathrm{~K}\right)$ : $\delta$ $34.2(\mathrm{br})$.

Reaction of $\operatorname{IrH}_{2}(\mathrm{Bpin})\left\{\mathrm{K}^{3}-\mathrm{P}, \mathrm{O}, \mathrm{P}-\left[\mathrm{xant}\left(\mathrm{P}^{\mathrm{i}} \mathrm{Pr}_{2}\right)_{2}\right]\right\}$ (2) with HBpin: Preparation of $\operatorname{IrH}(\mathrm{Bpin})_{2}\left\{\mathrm{~K}^{3}-\mathrm{P}, \mathrm{O}, \mathrm{P}-\left[\mathrm{xant}\left(\mathrm{P}^{\mathrm{i}} \mathrm{Pr}_{2}\right)_{2}\right]\right\}$ (3). A solution of 2 $(100 \mathrm{mg}, 0.13 \mathrm{mmol})$ in octane $(3 \mathrm{~mL})$ was treated with HBpin $(29 \mu \mathrm{L}$, $0.19 \mathrm{mmol}$ ) and the resulting mixture was refluxed for $30 \mathrm{~min}$. After cooling at room temperature the solution was evaporated to dryness, affording a yellowish residue. Pentane was added to afford a white solid. Yield: $86 \mathrm{mg}(74 \%)$. Anal. Calcd. for $\mathrm{C}_{39} \mathrm{H}_{65} \mathrm{~B}_{2} \mid \mathrm{IO}_{5} \mathrm{P}_{2}$ : C, 52.65; $\mathrm{H}, 7.36$. Found: $\mathrm{C}, 52.23 ; \mathrm{H}, 7.22$. HRMS (electrospray, $\mathrm{m} / \mathrm{z}$ ) calcd. for $\mathrm{C}_{39} \mathrm{H}_{65} \mathrm{~B}_{2} \mid \mathrm{rO}_{5} \mathrm{P}_{2}\left[\mathrm{IM}^{+}:\right.$: 889.4053; found: 889.4037. IR $\left(\mathrm{cm}^{-1}\right): \mathrm{v}(\mathrm{Ir}-\mathrm{H}) 1867$ (w), v(C-O-C) $1090(\mathrm{~m}) .{ }^{1} \mathrm{H}$ NMR $\left(400.13 \mathrm{MHz},\left[\mathrm{D}_{14}\right]\right.$ methylcyclohexane, $253 \mathrm{~K}): \delta 7.62\left(\mathrm{~m}, 2 \mathrm{H}, \mathrm{CH}\right.$-arom), $7.44\left(\mathrm{~d},{ }^{3} \mathrm{~J}_{\mathrm{H}-\mathrm{H}}=7.4,2 \mathrm{H}, \mathrm{CH}\right.$-arom), $7.25\left(\mathrm{t},{ }^{3} \mathrm{~J}_{\mathrm{H}-\mathrm{H}}=7.4,2 \mathrm{H}, \mathrm{CH}\right.$-arom), $2.89\left(\mathrm{~m}, 2 \mathrm{H}, \mathrm{PCH}\left(\mathrm{CH}_{3}\right)_{2}\right), 2.73(\mathrm{~m}, 2 \mathrm{H}$,
$\left.\mathrm{PCH}\left(\mathrm{CH}_{3}\right)_{2}\right), 1.98\left(\mathrm{~s}, 3 \mathrm{H}, \mathrm{CH}_{3}\right), 1.66\left(\mathrm{dvt},{ }^{3} \mathrm{~J}_{\mathrm{H}-\mathrm{H}}=7.2, N=14.8,6 \mathrm{H}\right.$, $\left.\mathrm{PCH}\left(\mathrm{CH}_{3}\right)_{2}\right), 1.56$ (dvt, $\left.{ }^{3} \mathrm{~J}_{\mathrm{H}-\mathrm{H}}=7.6, \mathrm{~N}=15.6,6 \mathrm{H}, \mathrm{PCH}\left(\mathrm{CH}_{3}\right)_{2}\right), 1.48(\mathrm{~s}, 3 \mathrm{H}$, $\left.\mathrm{CH}_{3}\right), 1.34$ (dvt, $\left.{ }^{3} \mathrm{~J}_{\mathrm{H}-\mathrm{H}}=7.2,6 \mathrm{H}, \mathrm{PCH}\left(\mathrm{CH}_{3}\right)_{2}\right), 1.35$ (s, $\left.12 \mathrm{H}, \mathrm{CH}_{3} \mathrm{Bpin}\right)$, $1.20\left(\mathrm{~s}, 12 \mathrm{H}, \mathrm{CH}_{3} \mathrm{Bpin}\right.$ ), 1.05 (dvt, ${ }^{3} \mathrm{~J}_{\mathrm{H}-\mathrm{H}}=7.2, \mathrm{~N}=14.4,6 \mathrm{H}, \mathrm{PCH}\left(\mathrm{CH}_{3}\right)_{2}$ ), $-5.66\left(\mathrm{t},{ }^{2} J_{\mathrm{H}-\mathrm{P}}=24.0, \quad 1 \mathrm{H}, \quad \mathrm{Ir}-\mathrm{H}\right) .{ }^{13} \mathrm{C}\left\{{ }^{1} \mathrm{H}\right\}$-apt NMR $(100.61 \mathrm{MHz}$, [D $\left.\mathrm{D}_{14}\right]$ methylcyclohexane, $253 \mathrm{~K}$ ): $\delta 158.2$ (vt, $N=10.4$, Carom), 133.2 (vt, $N=4.5$, Carom), 130.9 (s, CH-arom), 129.7 (vt, $N=30.9$, Carom), 125.6 (s, $\mathrm{CH}$-arom), 124.9 (s, CH-arom), 83.2, 81.4 (both s, C Bpin), 35.9 (s, $\left.\mathrm{C}\left(\mathrm{CH}_{3}\right)_{2}\right), 34.9\left(\mathrm{~s}, \mathrm{C}\left(\mathrm{CH}_{3}\right)_{2}\right), 32.6$ (vt, $\left.N=27.4, \mathrm{PCH}\left(\mathrm{CH}_{3}\right)_{2}\right), 30.1$ (vt, $N=$ 35.2, $\left.\mathrm{PCH}\left(\mathrm{CH}_{3}\right)_{2}\right), 27.7,26.2$ (both s, $\mathrm{CH}_{3}$ Bpin), $24.5\left(\mathrm{~s}, \mathrm{C}\left(\mathrm{CH}_{3}\right)_{2}\right), 21.9$, 21.6, 21.0, 20.9 (all s, $\left.\mathrm{PCH}\left(\mathrm{CH}_{3}\right)_{2}\right) .{ }^{31} \mathrm{P}\left\{{ }^{1} \mathrm{H}\right\}$ NMR (121.49 MHz, $\left[\mathrm{D}_{14}\right]$ methylcyclohexane, $298 \mathrm{~K}$ ): $\delta 49.1$ (s, doublet under off-resonance decoupling conditions). ${ }^{11} \mathrm{~B}\left\{{ }^{1} \mathrm{H}\right\}$ NMR (96.29 $\mathrm{MHz}$, $\left[\mathrm{D}_{14}\right]$ methylcyclohexane, $\left.298 \mathrm{~K}\right)$ : $\delta 38.4(\mathrm{br})$.

Reaction of $\operatorname{IrH}_{3}\left\{\kappa^{3}-\mathrm{P}, \mathrm{O}, \mathrm{P}-\left[\mathrm{xant}\left(\mathrm{P}^{\mathrm{i}} \mathrm{Pr}_{2}\right)_{2}\right]\right\}$ (1) with DBpin: Two Wilmad screw-cap NMR tubes were charged with $1(10 \mathrm{mg}, 0.016 \mathrm{mmol})$. To the first NMR tube was added $0.42 \mathrm{~mL}$ of cyclohexane and to the second was added $0.42 \mathrm{~mL}$ of $\left[\mathrm{D}_{12}\right]$ cyclohexane. DBpin $(3 \mu \mathrm{L}, 0.02 \mathrm{mmol})$ was added to both samples and they were periodically checked by NMR spectroscopy. After $6 \mathrm{~h}$ at room temperature, the ${ }^{1} \mathrm{H}$ and ${ }^{2} \mathrm{H}$ NMR spectra showed the presence of $2-\boldsymbol{d}_{1}$. The ${ }^{1} \mathrm{H}$ NMR $(300.13 \mathrm{MHz}$, $\left[D_{12}\right]$ cyclohexane, $298 \mathrm{~K}$ ) data were identical to those reported for 2 with the exception of the decrease of the intensity of the triplet at $-6.22 \mathrm{ppm}$ $\left({ }^{2} J_{\mathrm{H}-\mathrm{P}}=17.7 \mathrm{~Hz}\right)$ corresponding to $\mathrm{rH}_{2}$ and the appearance of a new triplet at $-6.08 \mathrm{ppm} \quad\left({ }^{2} J_{\mathrm{H}-\mathrm{P}}=17.7 \mathrm{~Hz}\right)$ corresponding to the $\mathrm{IrHD}$ isotopomer, being the deuterium incorporation at the hydride position $50 \%$. ${ }^{2} \mathrm{H} \mathrm{NMR}$ (46.07 MHz, cyclohexane, $298 \mathrm{~K}$ ): $\delta$-6.09 (s, IrD).

Reaction of $\mathrm{IrH}_{2}(\mathrm{Bpin})\left\{\mathrm{K}^{3}-\mathrm{P}, \mathrm{O}, \mathrm{P}-\left[\mathrm{xant}\left(\mathrm{P}^{\mathrm{i}} \mathrm{Pr}_{2}\right)_{2}\right]\right\}$ (2) with DBpin: Two Wilmad screw-cap NMR tubes were charged with 2 (10 mg, $0.013 \mathrm{mmol})$. To the first NMR tube was added $0.42 \mathrm{~mL}$ of cyclohexane and to the second was added $0.42 \mathrm{~mL}$ of $\left[\mathrm{D}_{12}\right]$ cyclohexane. DBpin $(3 \mu \mathrm{L}, 0.02$ $\mathrm{mmol}$ ) was added to both samples and they were periodically checked by NMR spectroscopy. After $30 \mathrm{~min}$ at $110^{\circ} \mathrm{C}$, the ${ }^{1} \mathrm{H}$ and ${ }^{2} \mathrm{H}$ NMR spectra showed the presence of $3-d_{1}$. The ${ }^{1} \mathrm{H}$ NMR $(300.13 \mathrm{MHz}$, $\left[D_{12}\right]$ cyclohexane, $298 \mathrm{~K}$ ) data were identical to those reported for 3 with the exception of the decrease of the intensity of the triplet at $-5.66 \mathrm{ppm}$ $\left({ }^{2} J_{\mathrm{H}-\mathrm{P}}=17.7 \mathrm{~Hz}\right)$ (corresponding to $\left.\mathrm{IHH}\right)$ and the appearance of a singlet in the ${ }^{2} \mathrm{H}$ NMR $(46.07 \mathrm{MHz}$, cyclohexane, $298 \mathrm{~K}$ ): $\delta-5.76$ (s, IrD) (corresponding to the $\mathrm{IrD}$ isotopomer).

NMR spectroscopic study of the transformation of $\operatorname{IrH}_{3}\left\{\mathrm{~K}^{3}-\mathrm{P}, \mathrm{O}, \mathrm{P}-\right.$

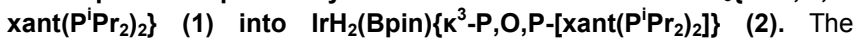
experimental procedure is described for a particular case, but the same method was used in all experiments, which were run in duplicate. In the glovebox, a Wilmad screw-cap NMR tube was charged with a solution of 1 (10 mg, $0.016 \mathrm{mmol})$, HBpin $(68 \mu \mathrm{L}, 0.47 \mathrm{mmol})$ in octane $(0.42 \mathrm{~mL})$, and a capillary tube filled with a solution of the internal standard $\left(\mathrm{PPh}_{3}\right)$ in $\left[D_{6}\right]$ benzene was placed in the NMR tube. The tube was immediately introduced into an NMR probe preheated at the desired temperature, and the reaction was monitored by ${ }^{31} \mathrm{P}\left\{{ }^{1} \mathrm{H}\right\} \mathrm{NMR}$ at different intervals of time.

Determination of the reaction order for HBpin in the transformation of 1 into 2 . The experimental procedure is analogous to that described for the transformation of 1 into 2 , starting form 1 ( $10 \mathrm{mg}, 0.016 \mathrm{mmol}, 0.0373 \mathrm{M}$ ) and variable concentrations of HBpin (from 0.747 to $1.495 \mathrm{M}$ ) in octane $(0.42 \mathrm{~mL})$. The experiments were carried out at $343 \mathrm{~K}$.

Determination of the reaction order for HBpin in the transformation of 2 into 3. The experimental procedure is analogous to that described for the transformation of 1 into 2 , starting form 2 (12 $\mathrm{mg}, 0.016 \mathrm{mmol}, 0.0374 \mathrm{M}$ ) and variable concentrations of HBpin (from 0.748 to $1.496 \mathrm{M}$ ) in octane $(0.42 \mathrm{~mL})$. The experiments were carried out at $343 \mathrm{~K}$.

NMR spectroscopic study of the transformation of $\operatorname{IrH}(B p i n)_{2}\left\{\mathrm{~K}^{3}-\right.$ $\left.P, O, P-x a n t\left(P^{i} P_{2}\right)_{2}\right\}$ (3) into $\operatorname{IrH}_{2}(B p i n)\left\{K^{3}-P, O, P-\left[x a n t\left(P^{i} P_{2}\right)_{2}\right]\right\}$ (2). The experimental procedure is described for a particular case, but the same 
method was used in all experiments, which were run in duplicate. In the glovebox, a Wilmad screw-cap NMR tube was charged with a solution of $3(14 \mathrm{mg}, 0.016 \mathrm{mmol})$ in benzene $(0.42 \mathrm{~mL})$, and a capillary tube filled with a solution of the internal standard $\left(\mathrm{PPh}_{3}\right)$ in $\left[\mathrm{D}_{6}\right]$ benzene was placed in the NMR tube. The tube was immediately introduced into an NMR probe preheated at the desired temperature, and the reaction was monitored by ${ }^{31} \mathrm{P}\left\{{ }^{1} \mathrm{H}\right\}$ NMR at different intervals of time.

NMR spectroscopic study of the transformation of $\operatorname{IrH}_{2}(\mathrm{Bpin})\left\{\mathrm{k}^{3}\right.$ $\left.P, O, P-\left[x a n t\left(P^{i} P_{2}\right)_{2}\right]\right\}$ (2) into $\operatorname{IrH}_{3}\left\{K^{3}-P, O, P-\left[x a n t\left(P^{i} P_{2}\right)_{2}\right]\right\} \quad$ (1). The experimental procedure is described for a particular case, but the same method was used in all experiments, which were run in duplicate. In the glovebox, a Wilmad screw-cap NMR tube was charged with a solution of $2(12 \mathrm{mg}, 0.016 \mathrm{mmol})$ in benzene $(0.42 \mathrm{~mL})$, and a capillary tube filled with a solution of the internal standard $\left(\mathrm{PPh}_{3}\right)$ in $\left[\mathrm{D}_{6}\right]$ benzene was placed in the NMR tube. The tube was immediately introduced into an NMR probe preheated at the desired temperature, and the reaction was monitored by ${ }^{31} \mathrm{P}\left\{{ }^{1} \mathrm{H}\right\}$ NMR at different intervals of time.

Optimization of the borylation reactions. In an argon-filled glovebox an Ace pressure tube was charged with complex $2(1.6 \mathrm{mg}, 0.002 \mathrm{mmol}$, $1 \mathrm{~mol} \%$; $3.9 \mathrm{mg}, 0.005 \mathrm{mmol}, 2.5 \mathrm{~mol} \%$ or $8 \mathrm{mg}, 0.01 \mathrm{mmol}, 5 \mathrm{~mol} \%$ ), HBpin $(30 \mu \mathrm{L}, 0.20 \mathrm{mmol})$ or $B_{2} \operatorname{pin}_{2}(26.2 \mathrm{mg}, 0.103 \mathrm{mmol}), 1 \mathrm{~mL}$ of benzene, and in the absence of presence of cyclohexene $(20 \mu \mathrm{L}, 0.20$ $\mathrm{mmol})$. The resulting mixture was stirred at $110{ }^{\circ} \mathrm{C}$ for variable times. After each time the arene was evaporated under reduced pressure to afford a crude reaction mixture. The yield of the borylation reactions was determined by ${ }^{1} \mathrm{H}$ NMR spectroscopy by dissolving the crude reaction mixture in [D]chloroform and adding $8 \mu \mathrm{L}(0.10 \mathrm{mmol})$ of 1,2 dichloroethane which was used as internal standard. In order to ensure accurate integration of the signals, the spectra were recorded using eight scans and 5 s delay.

General procedure for the borylation reactions. In an argon-filled glovebox an Ace pressure tube was charged with complex 2 (8 $\mathrm{mg}, 0.01$ $\mathrm{mmol})$, HBpin $(30 \mu \mathrm{L}, 0.20 \mathrm{mmol})$, cyclohexene $(20 \mu \mathrm{L}, 0.20 \mathrm{mmol})$ and 1 $\mathrm{mL}$ of the arene. The resulting mixture was stirred at $110^{\circ} \mathrm{C}$ for $18 \mathrm{~h}$. After this time the arene was evaporated under reduced pressure to afford a crude reaction mixture. The yield of the borylation reactions was determined by ${ }^{1} \mathrm{H}$ NMR spectroscopy by dissolving the crude reaction mixture in [D]chloroform and adding $8 \mu \mathrm{L}(0.10 \mathrm{mmol})$ of 1,2 dichloroethane which was used as internal standard. In order to ensure accurate integration of the signals, the spectra were recorded using eight scans and $5 \mathrm{~s}$ delay. The isolated yields were calculated after purification of the crude reaction mixture by flash chromatography over silica gel using diethyl ether as eluent and by evaporation to dryness.

Hydrogenation of cyclohexene catalyzed by $\operatorname{IrH}_{3}\left\{K^{3}-\mathrm{P}, \mathrm{O}, \mathrm{P}\right.$ [xant $\left(\mathbf{P}^{\mathrm{i}} \mathrm{Pr}_{2}\right)_{2}$ ] $\}$ (1). A solution of cyclohexene $(211 \mu \mathrm{L}, 2.01 \mathrm{mmol})$ in toluene $(1 \mathrm{~mL})$ was added, under hydrogen atmosphere, to a solution of 1 (15 mg, $0.02 \mathrm{mmol})$ in toluene $(7 \mathrm{~mL})$ placed into a $25 \mathrm{~mL}$ flask attached to a gas burette, which was in turn connected to a Schlenk manifold and had been previously evacuated and refilled with hydrogen. The flask was then immersed in a $40^{\circ} \mathrm{C}$ bath and the mixture was vigorously shaken $(500 \mathrm{rpm})$ during the run. The reaction was monitored by measuring the hydrogen consumption and by periodic $\mathrm{GC}$ analysis of samples removed via syringe. After $3 \mathrm{~h}$ total conversion of cyclohexene to cyclohexane was achieved.

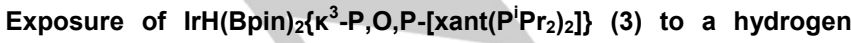
atmosphere. A low pressure/vacuum NMR tube was charged with a solution of $3(10 \mathrm{mg}, 0.01 \mathrm{mmol})$ in octane $(0.42 \mathrm{~mL})$, and the argon atmosphere was replaced by a hydrogen atmosphere (1 atm). The NMR tube was introduced in an oil bath at $50{ }^{\circ} \mathrm{C}$ and ${ }^{31} \mathrm{P}\left\{{ }^{1} \mathrm{H}\right\}$ NMR spectra were recorded periodically. After $8 \mathrm{~h}$ the complete conversion to $\mathbf{2}$ was observed.
Exposure of $\operatorname{IrH}_{2}(\mathrm{Bpin})\left\{\mathrm{K}^{3}-\mathrm{P}, \mathrm{O}, \mathrm{P}-\left[\mathrm{xant}\left(\mathrm{P}^{\mathrm{i}} \mathrm{Pr}_{2}\right)_{2}\right]\right\}$ (2) to a hydrogen atmosphere. A low pressure/vacuum NMR tube was charged with a solution of $2(10 \mathrm{mg}, 0.01 \mathrm{mmol})$ in octane $(0.42 \mathrm{~mL})$, and the argon atmosphere was replaced by a hydrogen atmosphere (1 atm). The NMR tube was introduced in an oil bath at $50{ }^{\circ} \mathrm{C}$ and ${ }^{31} \mathrm{P}\left\{{ }^{1} \mathrm{H}\right\}$ NMR spectra were recorded periodically. After $18 \mathrm{~h}$ the complete conversion to 1 was observed.

\section{Acknowledgements}

Financial support from the MINECO of Spain (Projects CTQ2017-82935-P and RED2018-102387-T (AEI/FEDER, UE)), Gobierno de Aragón (Group E06_20R, project LMP148_18, and predoctoral contract to A.M.), FEDER, and the European Social Fund is acknowledged.

Keywords: arene borylation $\bullet$ B-H activation $\bullet \mathrm{C}-\mathrm{H}$ activation $\bullet$ iridium • pincer ligand •

[1] a) J. F. Hartwig, J. Am. Chem. Soc. 2016, 138, 2-24; b) J. F. Hart-wig M. A. Larsen, ACS Cent. Sci. 2016, 2, 281-292; c) H. M. L. Davies, D. Morton J. Org. Chem. 2016, 81, 343-350; d) N. J. Gunsalus, A Koppaka, S. H. Park, S. M. Bischof, B. G. Hashiguchi, R. A. Periana, Chem. Rev. 2017, 117, 8521-8573.

[2] a) W. D. Jones, F. J. Feher, Acc. Chem. Res. 1989, 22, 91-100; b) A. E. Shilov, G. B. Shul'pin, Chem. Rev. 1997, 97, 2879-2932; c) D. Balcells, E. Clot, O. Eisenstein, Chem. Rev. 2010, 110, 749-823; d) X.-S. Xue, P. Ji, B. Zhou, J.-P. Cheng, Chem. Rev. 2017, 117, 8622-8648.

[3] a) Y. Park, Y. Kim, S. Chang, Chem. Rev. 2017, 117, 9247-9301; b) J. R. Hummel, J. A. Boerth, J. A. Ellman, Chem. Rev. 2017, 117, 91639227; (c) M. A. Esteruelas, M. Oliván in Applied Homogeneous Catalysis with Organometallic Compounds: A Comprehensive Handbook in Four Volumes, 3rd Edition (Eds.: B. Cornils, W. A Herrmann, M. Beller, R. Paciello), Wiley-VCH, 2017, chapter 23, pp 1307-1332.

[4] a) Boronic Acids: Preparation and Applications in Organic Synthesis Medicine and Materials, 2nd ed. (Ed.: D. G. Hall), Wiley-VCH: Weinheim, 2011; b) J. Carreras, A. Caballero, P. J. Perez, Chem. Asian J. 2019, 14, 329-343.

[5] a) I. A. I. Mkhalid, J. H. Barnard, T. B. Marder, J. M. Murphy, J. F. Hartwig, Chem. Rev. 2010, 110, 890-931; b) J. F. Hartwig, Chem. Soc Rev. 2011, 40, 1992-2002; c) J. F. Hartwig, Acc. Chem. Res. 2012, 45 864-873; d) A. Ros, R. Fernández, J. M. Lassaletta, Chem. Soc. Rev. 2014, 43, 3229-3243; e) L. Xu, G. Wang, S. Zhang, H. Wang, L. Wang L. Liu, J. Jiao, P. Li, Tetrahedron 2017, 73, 7123-7157; f) Y. Kuroda, Y. Nakao, Chem. Lett. 2019, 48, 1092-1100.

[6] a) T. J. Mazzacano, N. P. Mankad, Chem. Commun. 2015, 51, 53795382; b) T. Dombray, C. G. Werncke, S. Jiang, M. Grellier, L. Vendier S. Bontemps, J.-B. Sortais, S. Sabo-Etienne, C. Darcel, J. Am. Chem. Soc. 2015, 137, 4062-4065; c) T. Kato, S. Kuriyama, K. Nakajima, Y Nishibayashi, Chem. Asian J. 2019, 14, 2097-2101; d) M. Kamitani, H. Kusaka, H. Yuge, Chem. Lett. 2019, 48, 898-901.

[7] a) J. V. Obligacion, S. P. Semproni, P. J. Chirik, J. Am. Chem. Soc. 2014, 136, 4133-4136; b) B. A. Schaefer, G. W. Margulieux, B. L. Small, P. J. Chirik, Organometallics 2015, 34, 1307-1320; c) J. V. Obligacion, S. P. Semproni, I. Pappas, P. J. Chirik, J. Am. Chem. Soc. 2016, 138, 10645-10653; d) H. Ren, Y.-P. Zhou, Y. Bai, C. Cui, M. Driess, Chem. Eur. J. 2017, 23, 5663-5667; e) J. V. Obligacion, M. J. Mbezdek, P. J. Chirik, J. Am. Chem. Soc. 2017, 139, 2825-2832; f) N. G. Léonard, M. J. Bezdek, P. J. Chirik, Organometallics 2017, 36, 142-150; g) J. V. Obligacion, H. Zhong, P. J. Chirik, Isr. J. Chem. 2017, 57, 1032-1036; (h) J. V. Obligacion, P. J. Chirik, ACS Catal. 2017, 7, 4366-4371; i) H. Li, J. V Obligacion, P. J. Chirik, M. B. Hall, ACS Catal. 2018, 8, 1060610618; j) T. P. Pabst, J. V. Obligacion, E. Rochette, I. Pappas, P. J. Chirik, J. Am. Chem. Soc. 2019, 141, 15378-15389. 
[8] a) M. A. Esteruelas, M. Oliván, A. Vélez, Organometallics 2015, 34 1911-1924; b) C.-I. Lee, N. A. Hirscher, J. Zhou, N. Bhuvanesh, O. V. Ozerov, Organometallics 2015, 34, 3099-3102.

[9] a) T. Furukawa, M. Tobisu, N. Chatani, Chem. Commun. 2015, 51, 6508-6511; b) A. Das, P. K. Hota, S. K. Mandal, Organometallics 2019 38, 3286-3293.

[10] a) T. Furukawa, M. Tobisu, N. Chatani, J. Am. Chem. Soc. 2015, 137, 12211-12214; b) J. Takaya, S. Ito, H. Nomoto, N. Saito, N. Kirai, N. Iwasawa, Chem. Commun. 2015, 51, 17662-17665.

[11] a) T. Ishiyama, J. Takagi, K. Ishida, N. Miyaura, N. R. Anastasi, J. F. Hartwig, J. Am. Chem. Soc. 2002, 124, 390-391; b) T. Ishiyama, J. Takagi, J. F. Hartwig, N. Miyaura, Angew. Chem. Int. Ed. 2002, 41 3056-3058; c) T. Ishiyama, J. Takagi, Y. Yonekawa, J. F. Hartwig, N Miyaura, Adv. Synth. Catal. 2003, 345, 1103-1106; d) G. A. Chotana, M. A. Rak, M. R. Smith III, J. Am. Chem. Soc. 2005, 127, 10539-10544; e) J. M. Murphy, X. Liao, J. F. Hartwig, J. Am. Chem. Soc. 2007, 129, 15434-15435; f) M. A. Larsen, J. F. Hartwig, J. Am. Chem. Soc. 2014 136, 4287-4299; g) F. Wu, Y. Feng, C. W. Jones, ACS Catal. 2014, 4, 1365-1375; (h) C. R. K. Jayasundara, J. M. Unold, J. Oppenheimer, M. R. Smith III, R. E. Maleczka Jr, Org. Lett. 2014, 16, 6072-6075; i) K. M. Crawford, T. R. Ramseyer, C. J. A. Daley, T. B. Clark, Angew. Chem. Int. Ed. 2014, 53, 7589-7593; j) L. V. A. Hale, K. A. McGarry, M. A Ringgold, T. B. Clark, Organometallics 2015, 34, 51-55; k) F. Batool, S Parveen, A.-H. Emwas, S. Sioud, X. Gao, M. A. Munawar, G. A Chotana, Org. Lett. 2015, 17, 4256-4259. I) B. Su, T.-G- Zhou, P.-L. Xu Z.-J. Shi, J. F. Hartwig, Angew. Chem. Int. Ed. 2017, 56, 7205-7208; m) H. Mamlouk, J. Suriboot, P. K. Kumar Manyam, A. AlYazidi, D. E. Bergbreiter, S. T. Madrahimov, Catal. Sci. Technol. 2018, 8, 124-127 n) J. R. Montero Bastidas, T. J. Oleskey, S. L. Miller, M. R. Smith III, R. E. Maleczka Jr, J. Am. Chem. Soc. 2019, 141, 15483-15487.

[12] a) J.-Y. Cho, M. K. Tse, D. Holmes, R. E. Maleczka Jr, M. R. Smith III Science 2002, 295, 305-308; b) G. A. Chotana, B. A. Vanchura II, M. K Tse, R. J. Staples, R. E. Maleczka Jr, M. R. Smith III, Chem. Commun. 2009, 5731-5733; c) Y. Saito, Y. Segawa, K. Itami, J. Am. Chem. Soc. 2015, 137, 5193-5198; d) B. Ghaffari, B. A. Vanchura II, G. A. Chotana R. J. Staples, D. Holmes, R. E. Maleczka Jr, M. R. Smith III Organometallics 2015, 34, 4732-4740; e) M. T. Mihai, B. D. Williams, R. J. Phipps, J. Am. Chem. Soc. 2019, 141, 15477-15482.

[13] a) S. M. Preshlock, B. Ghaffari, P. E. Maligres, S. W. Krska, R. E. Maleczka Jr, M. R. Smith III, J. Am. Chem. Soc. 2013, 135, 7572-7582 b) R. J. Oeschger, M. A. Larsen, A.; Bismuto, J. F. Hartwig, J. Am. Chem. Soc. 2019, 141, 16479-16485.

[14] a) H. Tamura, H. Yamazaki, H. Sato, S. Sakaki, J. Am. Chem. Soc. 2003, 125, 16114-16126; b) T. M. Boller, J. M. Murphy, M. Hapke, T. Ishiyama, N. Miyaura, J. F. Hartwig, J. Am. Chem. Soc. 2005, 127, 14263-14278; c) T. Ishiyama, N. Miyaura, Pure Appl. Chem. 2006, 78 1369-1375; d) B. A. Vanchura II, S. M. Preshlock, P. C. Roosen, V. A Kallepalli, R. J. Staples, R. E. Maleczka Jr, D. A. Singleton, M. A. Smith III, Chem. Commun. 2010, 46, 7724-7726; e) A. G. Green, P. Liu, C. A. Merlic, K. N. Houk, J. Am. Chem. Soc. 2014, 136, 4575-4583.

[15] a) G. Wang, L. Xu, P. Li, J. Am. Chem. Soc. 2015, 137, 8058-8061; (b) G. Wang, L. Liu, H. Wang, Y.-S. Ding, J. Zhou, S. Mao, P. Li, J. Am. Chem. Soc. 2017, 139, 91-94.

[16] B. Ghaffari, S. M. Preshlock, D. L. Plattner, R. J. Staples, P. E. Maligres, S. W. Krska, R. E. Maleczka Jr, M. R. Smith III, J. Am. Chem. Soc. 2014, 136, 14345-14348.

[17] a) J. R. Khusnutdinova, D. Milstein, Angew. Chem. Int. Ed., 2015, 54, 12236-12273; b) A. Kumar, T. M. Bhatti, A. S. Goldman, Chem. Rev. 2017, 117, 12357-12384; (c) H. Valdés, M. A. García-Eleno, D. Canseco-Gonzalez, D. Morales-Morales, ChemCatChem 2018, 10 3136-3172.

[18] a) A. R. Chianese, A. Mo, N. L. Lampland, R. L. Swartz, P. T. Bremer, Organometallics 2010, 29, 3019-3026; b) H. Fang, Y.-K. Choe, Y. Li, S. Shimada, Chem. Asian J. 2011, 6, 2512-2521; c) J. Ito, T. Kaneda, H. Nishiyama, Organometallics 2012, 31, 4442-4449; d) A. Brück, D. Gallego, W. Wang, E. Irran, M. Driess, J. F. Hartwig, Angew. Chem. Int Ed. 2012, 51, 11478-11482; e) L. P. Press, A. J. Kosanovich, B. J. McCulloch, O. V. Ozerov, J. Am. Chem. Soc. 2016, 138, 9487-9497; f) S. Ding, L. Wang, Z. Miao, P. Li, Molecules 2019, 24, 1434.
[19] a) D. H. Nguyen, J. J. Pérez-Torrente, L. Lomba, M. V. Jiménez, F. J. Lahoz, L. A. Oro, Dalton Trans. 2011, 40, 8429-8435; b) D. H. Nguyen J. J. Pérez-Torrente, M. V. Jiménez, F. J. Modrego, D. Gómez-Bautista, F. J. Lahoz, L. A. Oro, Organometallics 2013, 32, 6918-6930.

[20] a) L. A. van der Veen, P. H. Keeven, G. C. Schoemaker, J. N. H. Reek, P. C. J. Kamer, P. W. N. M. van Leeuwen, M. Lutz, A. L. Spek, Organometallics 2000, 19, 872-883; b) G. L. Moxham, H. E. RandellSly, S. K. Brayshaw, R. L. Woodward, A. S. Weller, M. C. Willis, Angew Chem. Int. Ed. 2006, 45, 7618-7622; c) G. L. Moxham, H. Randell-Sly, S. K. Brayshaw, A. S. Weller, M. C. Willis, Chem. Eur. J. 2008, 14 8383-8397; d) A. E. W. Ledger, M. F. Mahon, M. K. Whittlesey, J. M. Williams, Dalton Trans. 2009 6941-6947; e) G. L. Williams, C. M. Parks, C. R. Smith, H. Adams, A. Haynes, A. J. H. M. Meijer, G. J. Sunley, S. Gaemers, Organometallics 2011, 30,6166-6179; f) R. Dallanegra, A. B Chaplin, A. S. Weller, Organometallics 2012, 31, 2720-2728; g) H. C. Johnson, C. L. McMullin, S. D. Pike, S. A. Macgregor, A. S. Weller, Angew. Chem. Int. Ed. 2013, 52, 9776-9780; h) W. Baumann, A Spannenberg, J. Pfeffer, T. Haas, A. Köckritz, A. Martin, J. Deutsch, Chem. Eur. J. 2013, 19, 17702-17706; i) H. C. Johnson, E. M. Leitao, G. R. Whittell, I. Manners, G. C. Lloyd-Jones, A. S. Weller, J. Am. Chem. Soc. 2014, 136, 9078-9093; j) H. C. Johnson, R. Torry-Harris, L. Ortega, R. Theron, J. S. McIndoe, A. S. Weller, Catal. Sci. Technol. 2014, 4 , 3486-3494; k) S. C. Ensign, E. P. Vanable, G. D. Kortman, L. J. Weir, K. L. Hull, J. Am. Chem. Soc. 2015, 137, 13748-13751; I) T. E. Stevens, K. A. Smoll, K. I. Goldberg, J. Am. Chem. Soc. 2017, 139, 7725-7728; m) C. Karmel, B. Li, J. F. Hartwig, J. Am. Chem. Soc. 2018, 140, 14601470; n) J. Barwick-Silk, S. Hardy, M. C. Willis, A. S. Weller, J. Am. Chem. Soc. 2018, 140, 7347-7357; o) P. W. N. M. van Leeuwen, P. C. J. Kamer, Catal. Sci. Technol. 2018, 8, 26-113; p) G. M. Adams, A. S Weller, Coord. Chem. Rev. 2018, 355, 150-172; q) G. M. Adams, D. E. Ryan, N. A. Beattie, A. I. McKay, G. C. Lloyd-Jones, A. S. Weller, ACS Catal. 2019, 9, 3657-3666.

[21] G. Asensio, A. B. Cuenca, M. A. Esteruelas, M. Medio-Simón, M. Oliván, M. Valencia, Inorg. Chem. 2010, 49, 8665-8667.

[22] a) M. A. Esteruelas, M. Oliván, A. Vélez, Inorg. Chem. 2013, 52, 5339 5349; b) J. Alós, M. A. Esteruelas, M. Oliván, E. Oñate, P. Puylaert, Organometallics 2015, 34, 4908-4921; c) S. G. Curto, M. A. Esteruelas M. Oliván, E. Oñate, A. Vélez, Organometallics 2017, 36, 114-128; d) M. A. Esteruelas, I. Fernández, C. García-Yebra, J. Martín, E. Oñate, Organometallics 2017, 36, 2298-2307; e) M. A. Esteruelas, I. Fernández, C. García-Yebra, J. Martín, E. Oñate, Inorg. Chem. 2019, 58, 2265-2269.

[23] M. A. Esteruelas, I. Fernández, A. Martínez, M. Oliván, E. Oñate, A Vélez, Inorg. Chem. 2019, 58, 4712-4717.

[24] a) V. I. Bakhmutov, F. Bozoglian, K. Gómez, G. González, V. V. Grushin, S. A. Macgregor, E. Martin, F. E. Miloserdov, M. A. Novikov, J. A.; Panetier, L. V. Romashov, Organometallics 2012, 31, 1315-1328; b) J. Alós, T. Bolaño, M. A. Esteruelas, M Oliván, E. Oñate, M. Valencia, Inorg. Chem. 2013, 52, 6199-6213; c) J. Jover, F. M. Miloserdov, J. Benet-Buchholz, V. V. Grushin, F. Maseras, Organometallics, 2014, 33, 6531-6543; d) M. A. Esteruelas, P. Nolis, M. Oliván, E. Oñate, A. Vallribera, A. Vélez, Inorg. Chem. 2016, 55, 7176-7181; e) M. A Esteruelas, C. García-Yebra, J. Martín, E. Oñate, Inorg. Chem. 2017 56, 676-683; f) A. Antiñolo, M. A. Esteruelas, C. García-Yebra, J Martín, E. Oñate, A. Ramos, Organometallics 2019, 38, 310-318.

[25] a) M. A. Esteruelas, M. Oliván, A. Vélez, Inorg. Chem. 2013, 52, 1210812119 ; b) M. A. Esteruelas, C. García-Yebra, J. Martín, E. Oñate, ACS Catal. 2018, 8, 11314-11323.

[26] a) J. Alós, T. Bolaño, M. A. Esteruelas, M. Oliván, E. Oñate, M. Valencia, Inorg. Chem. 2014, 53, 1195-1209; b) S. G. Curto, L. A. de las Heras, M. A. Esteruelas, M. Oliván, E. Oñate, Organometallics 2019, 38, 3074-3083.

[27] a) M. A. Esteruelas, M. Oliván, A. Vélez, J. Am. Chem. Soc. 2015, 137, 12321-12329; b) S. G. Curto, M. A. Esteruelas, M. Oliván, E. Oñate, A Vélez, Organometallics 2018, 37, 1970-1978; c) S. G. Curto, M. A. Esteruelas, M. Oliván, E. Oñate, Organometallics 2019, 38, 2062-2074 d) S. G. Curto, M. A. Esteruelas, M. Oliván, E. Oñate, Organometallics 2019, 38, 4183-4192. 
[28] J. D. Atwood, in Inorganic and Organometallic Reaction Mechanisms; VCH: New York, 1977; chapter 3.

[29] M. A. Esteruelas, A. M. López, M. Oliván, Chem. Rev. 2016, 116, 8770 8847.

[30] a) D. R. Lantero, D. L. Ward, M. R. Smith III, J. Am. Chem. Soc. 1997 119, 9699-9708; b) V. Montiel-Palma, M. Lumbierres, B. Donnadieu, S. Sabo-Etienne, B. Chaudret, J. Am. Chem. Soc. 2002, 124, 5624-5625; c) S. A. Westcott, T. B. Marder, R. T. Baker, R. L. Harlow, J. C Calabrese, K. C. Lam, Polyhedron 2004, 23, 2665-2677; d) S. Lachaize K. Essalah, V. Montiel-Palma, L. Vendier, B. Chaudret, J.-C. Barthelat, S. Sabo-Etienne, Organometallics 2005, 24, 2935-2943; e) S Bontemps, L. Vendier, S. Sabo-Etienne, Angew. Chem. Int. Ed. 2012 51, 1671-1674; f) C. Gunanathan, M. Hölscher, F. Pan, W. Leitner, J. Am. Chem. Soc. 2012, 134, 14349-14352; g) S. Chakraborty, J. Zhang, Y. J. Patel, J. A. Krause, H. Guan, Inorg. Chem. 2013, 52, 37-47; h) M. A. Esteruelas, A. M. López, M. Mora, E. Oñate, Organometallics 2015, 34, 941-946; i) N. Arnold, S. Mozo, U. Paul, U. Radius, H. Braunschweig, Organometallics 2015, 34, 5709-5715; j) A. Kumar, J. S A. Ishibashi, T. N. Hooper, T. C. Mikulas, D. A. Dixon, S.-Y. Liu, A. S. Weller, Chem. Eur. J. 2016, 22, 310-322; k) J. C. Babón, M. A Esteruelas, I. Fernández, M. A. López, E. Oñate, Inorg. Chem. 2018 57, 4482-4491.

[31] a) I. Demachy, M. A. Esteruelas, Y. Jean, A. Lledós, F. Maseras, L. A. Oro, C. Valero, F. Volatron, J. Am. Chem. Soc. 1996, 118, 8388-8394; b) A. Antiñolo, F. Carrillo-Hermosilla, J. Fernández-Baeza, S. GarcíaYuste, A. Otero, A. M. Rodríguez, J. Sánchez-Prada, E. Villaseñor, R. Gelabert, M. Moreno, J. M. Lluch, A. Lledós, Organometallics 2000, 19, 3654-3663.

[32] a) R. H. Crabtree, A. Habib, Inorg. Chem. 1986, 25, 3698-3699; b) M. T. Bautista, E. P. Cappellani, S. D. Drouin, R. H. Morris, C. T. Schweitzer, A. Sella, J. Zubkowski. J. Am. Chem. Soc. 1991, 113, 4876-4877; c) M Paneque, M. L. Poveda, S. Taboada, J. Am. Chem. Soc. 1994, 116, 4519-4520.

[33] M. Gómez-Gallego, M. A. Sierra, Chem. Rev. 2011, 111, 4857-4963.

[34] a) M. E. Evans, C. L. Burke, S. Yaibuathes, E. Clot, O. Eisenstein, W. D. Jones, J. Am. Chem. Soc. 2009, 131, 13464-13473; b) E. Clot, C Mégret, O. Eisenstein, R. N. Perutz, J. Am. Chem. Soc. 2009, 131 7817-7827; c) T. Tanabe, W. W. Brennessel, E. Clot, O. Eisenstein, W. D. Jones, Dalton Trans. 2010, 39, 10495-10509.
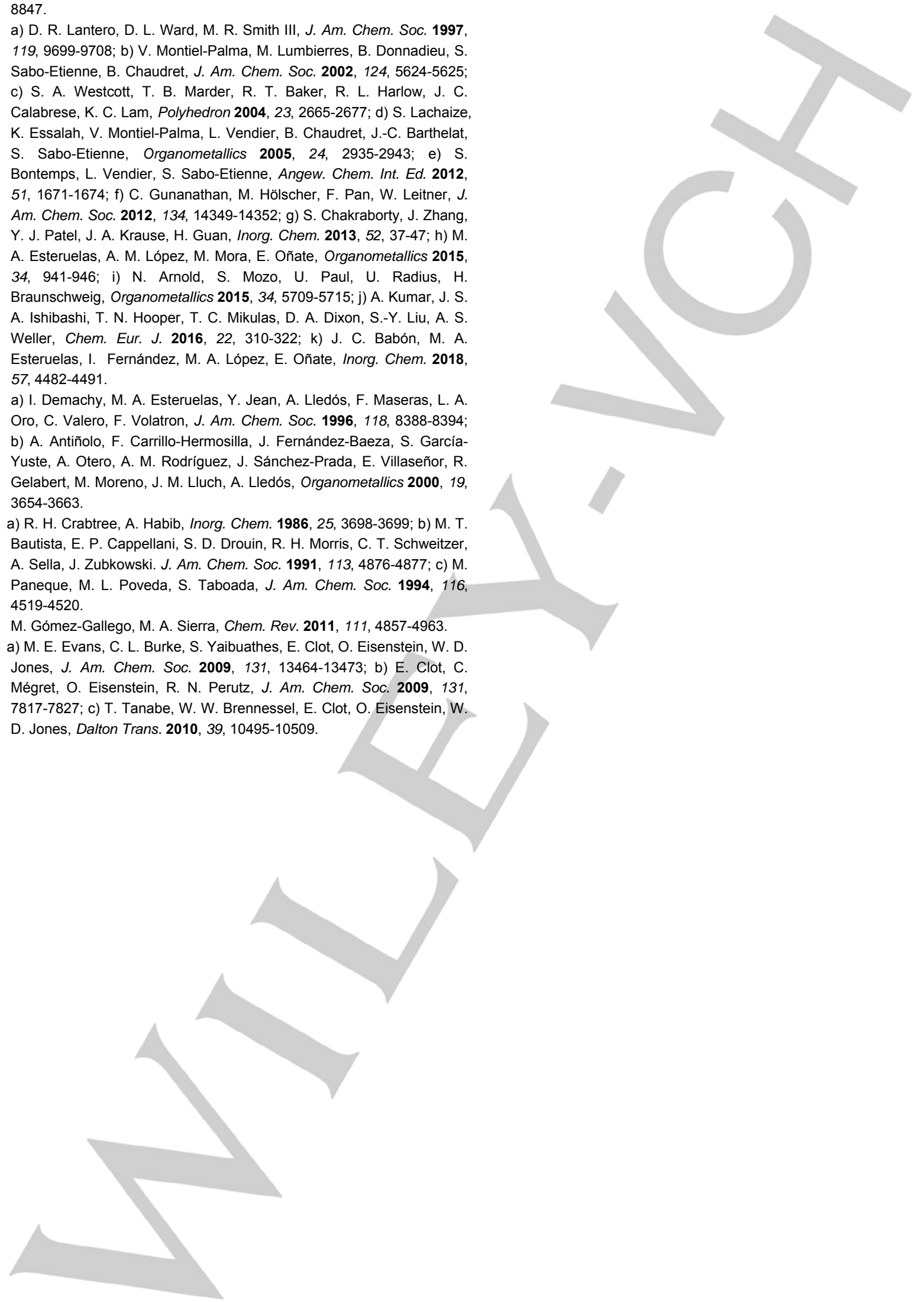


\section{Entry for the Table of Contents}

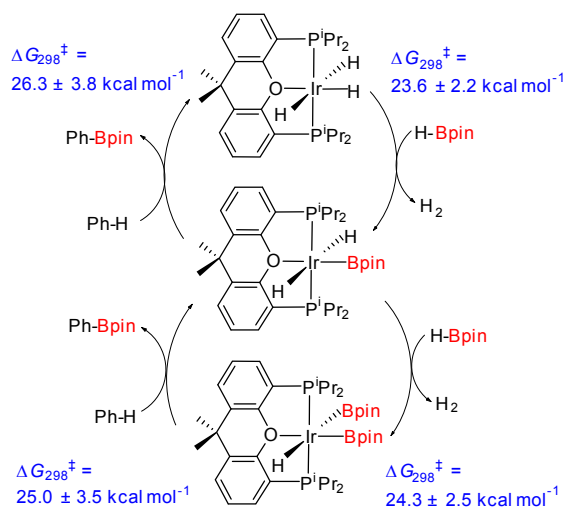

Complexes $\operatorname{IrH} H_{3}\left\{\mathrm{~K}^{3}-\mathrm{P}, \mathrm{O}, \mathrm{P}-\left[\mathrm{xant}\left(\mathrm{P}^{\mathrm{i}} \mathrm{Pr}_{2}\right)_{2}\right]\right\}, \operatorname{IrH} \mathrm{H}_{2}(\mathrm{Bpin})\left\{\mathrm{K}^{3}-\mathrm{P}, \mathrm{O}, \mathrm{P}-\left[\mathrm{xant}\left(\mathrm{P}^{\mathrm{i}} \mathrm{Pr}_{2}\right)_{2}\right]\right\}$, and $\operatorname{IrH}(\mathrm{Bpin})_{2}\left\{\mathrm{~K}^{3}-\mathrm{P}, \mathrm{O}, \mathrm{P}-\left[\mathrm{xant}\left(\mathrm{P}^{\mathrm{i}} \mathrm{Pr}_{2}\right)_{2}\right]\right\}$ are connected through $\mathrm{B}-\mathrm{H}$ and $\mathrm{C}-\mathrm{H}$ bond activations of $\mathrm{HBpin}$ and benzene, respectively, and define two cycles for the $\mathrm{C}-\mathrm{H}$ borylation of arenes with $\mathrm{HBpin}$, having $\mathrm{IrH}_{2}(\mathrm{Bpin})\left\{\mathrm{K}^{3}-\mathrm{P}, \mathrm{O}, \mathrm{P}-\left[\mathrm{xant}\left(\mathrm{P}^{\mathrm{i} P \mathrm{Pr}_{2}}\right)_{2}\right]\right\}$ as common intermediate. Kinetic measurements reveal that the rate determining step of both cycles is the $\mathrm{C}-\mathrm{H}$ activation of the arene. 